\title{
WELFARE EFFECTS OF HOUSING PRICE APPRECIATION IN AN ECONOMY WITH BINDING CREDIT CONSTRAINTS
}

\section{Ashot Tsharakyan}
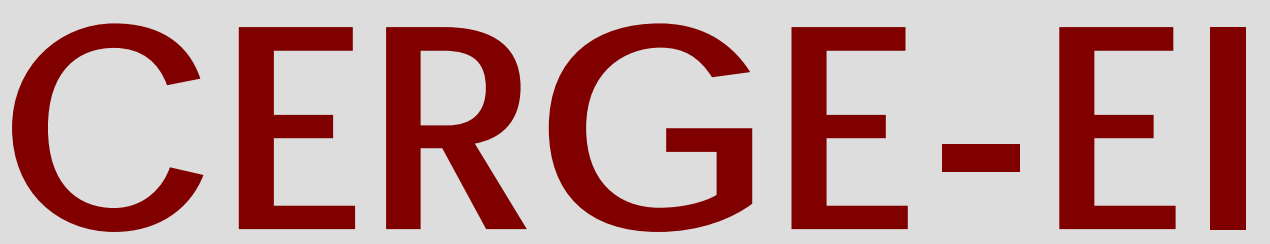

Charles University CenterforEconomic Research and Graduate Education Academy of Sciences of the Czech Republic Ec onomic s Institute 


\title{
Working Paper Series 333 (ISSN 1211-3298)
}

\section{Welfare Effects of Housing Price Appreciation in an Economy With Binding Credit Constraints}

\author{
Ashot Tsharakyan
}

CERGE-EI

Prague, July 2007 
ISBN 978-80-7343-132-7 (Univerzita Karlova. Centrum pro ekonomický výzkum a doktorské studium)

ISBN 978-80-7344-121-0 (Národohospodářský ústav AV ČR, v.v.i.) 


\title{
Welfare Effects of Housing Price Appreciation in an Economy With Binding Credit Constraints
}

\author{
Ashot Tsharakyan* \\ CERGE-EI ${ }^{\dagger}$ \\ June 2007
}

\begin{abstract}
This research analyzes the effects of recent housing price appreciation on aggregate welfare. It generalizes the results of Bajari et al (2005), who find that in a credit unconstrained economy with exogenous housing prices there is no effect of housing price appreciation on aggregate welfare. However, I demonstrate that if the households are credit-constrained and housing price is endogenous its appreciation implies a non-zero change in aggregate welfare. First, credit constraints are incorporated into Bajari et al's model and it is shown that if they are binding housing price appreciation implies an improvement in aggregate welfare. I then construct a model where housing price appreciation is endogenous and is driven by demand and supplyside shocks. The supply shock results from a change in building permit cost. The demand shifts are generated based on dynamics of household income and interest rates. Both credit-constrained and unconstrained versions of this model are considered. Afterwards, using my theoretical results I calculate the aggregate welfare effects of housing price appreciation driven by the combination of demand-side and supply-side shocks observed in the US housing market from 1995 to 2004. The final result implies that housing price appreciation in 1995-2004 driven by the given combination of demand and supply-side shocks led to per household improvement of aggregate welfare by an amount equivalent to about 40\% of mean household income in 2004 .
\end{abstract}

\section{JEL classification: R2, R20, R21, R31}

Keywords: housing price appreciation, aggregate welfare, binding credit constraints, endogenous housing price, demand and supply side shocks, median household income

I would like to thank Petr Zemcik for very valuable help and supervision of this paper and Randy Filer, Libor Dusek, Peter Katuscak and Michal Kejak for the useful and valuable comments on the earlier drafts.

${ }^{\dagger}$ CERGE-EI is a joint workplace of the Center for Economic Research and Graduate Education, Charles University, and the Economics Institute of Academy of Sciences of the Czech Republic.

Address: CERGE-EI, P.O. Box 882, Politických věznư 7, Prague 1, 111 21, Czech Republic

* Email: atsharak@,cerge-ei.cz 


\begin{abstract}
Abstrakt
Tento výzkum analyzuje efekty nedávného zvýšení cen bydlení na celkové bohatství. Zobecňuje výsledky Bajari et al (2005), kteří zjistili, že v ekonomice bez omezení na půjčky s exogenními cenami bydlení nemá zvýšení cen bydlení žádný efekt na celkové bohatství. Já ale ukazuji, že když jsou půjčky domácnosti omezeny a ceny bydlení jsou endogenní, pak jejich zvýšení znamená nenulovu změnu v celkovém bohatství. Nejprve do modelu Bajari et al zakomponuji omezení na půjčky a pak ukáži, že když je omezení na půjčování aktivní, znamená zvýšení cen bydlení zvýšení celkového bohatství. Poté sestavím model, kde je zvýšení cen bydlení endogenní a závisí na výskytu poptávkových a nabídkových šoků. Nabídkový šok je výsledkem změny $\mathrm{v}$ nákladech na stavební povolení. Posuny $\mathrm{v}$ poptávce vychází $\mathrm{z}$ dynamiky prrijmů domácností a úrokových měr. $\mathrm{V}$ úvahu beru obě varianty modelu, jak $\mathrm{s}$ omezením na půjčky, tak bez něj. Poté za použití svých teoretických výsledků vypočítám efekty zvýšení cen bydlení vyvolaného poptávkovými a nabídkovými šoky pozorovanými na trhu bydlení v USA v letech 1995-2004 na celkové bohatství. Závěrečný výsledek ukazuje, že zvýšení cen bydlení v letech 1995-2004 jako důsledek kombinace poptávkových a nabídkových šoků vedlo k průměrnému zvýšení bohatství domácností o ekvivalent 40\% jejich průměrného př́ijmu v roce 2004.
\end{abstract}




\section{Introduction}

Recent economic development in the majority of industrialized countries has been characterized by considerable change in housing prices. Particularly in the United States during the last decade housing prices have risen at a rate exceeding growth rate of income and all other asset prices (Bajari et al (2005), Li and Yao(2004)). Also, according to the Monthly Interest Rate Survey of Federal Housing Finance Board between 1986 and 1994 the average purchasing price of housing in US increased by 28.4\% while between 1996 and 2004 it increased by $68.9 \%$. Constant-quality housing price index published by the US Census Bureau gives a similar picture, showing that between 1986 and 1994, holding housing quality constant, housing prices appreciated by $22.1 \%$ while between 1996 and 2004 they increased by $41.9 \%$.Figure 1 displays the dynamics of median price of single-family homes and the dynamics of constant-quality prices in US from 1986 to 2004.

\section{FIGURE 1}

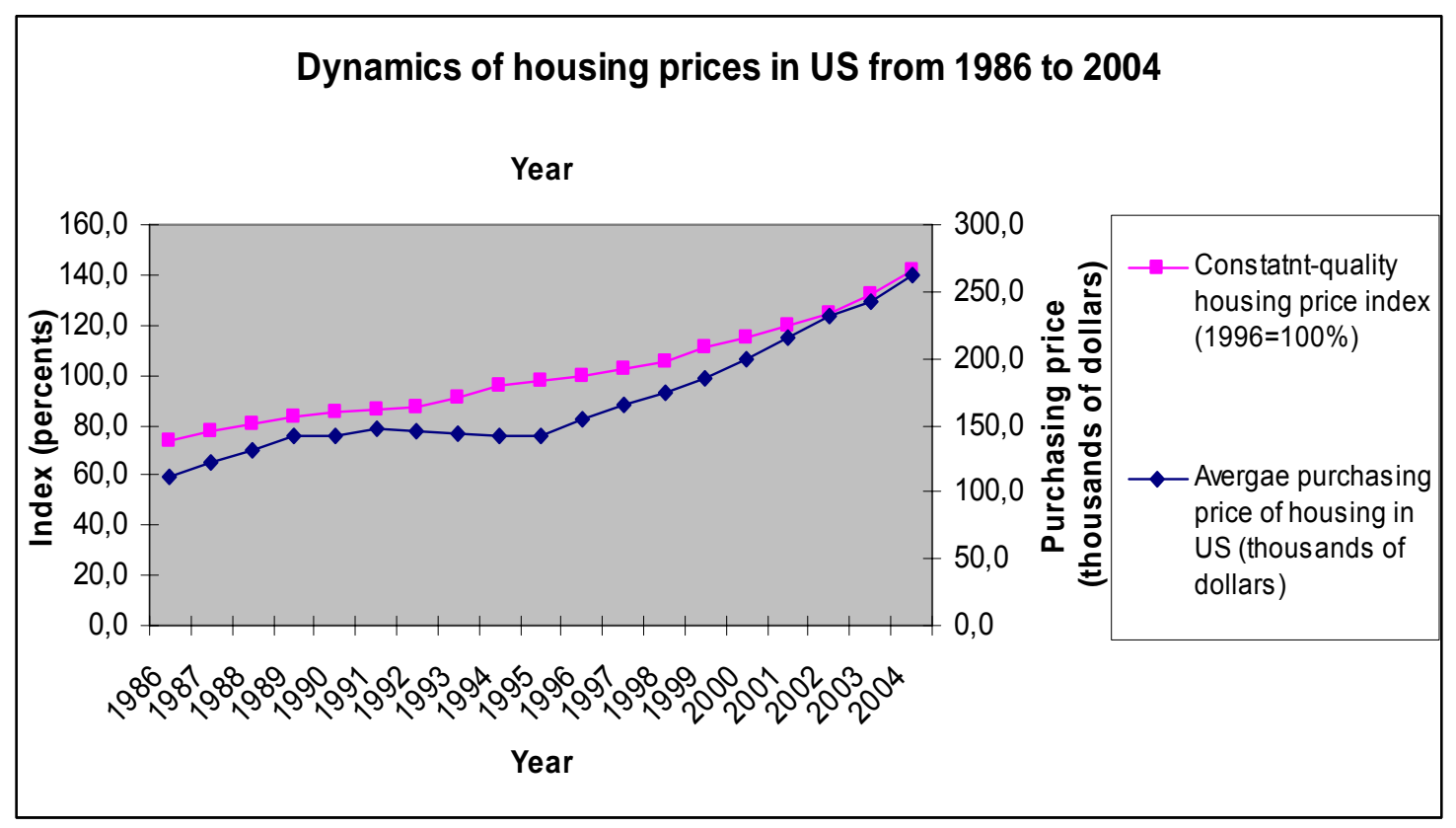

* Source: US Census Bureau, Federal Housing Finance Board

Such substantial appreciation has stimulated research on the different possible macroeconomic effects of housing price appreciation, particularly its link with monetary 
policy, its role in the business cycle and most importantly, its effects on consumption and consumer welfare (see for example Iacoviello and Minetti(2003), Iacoviello(2004), Iacaviello(2005), Campbell and Cocco(2005), Li and Yao(2004), Bajari et al(2005)).

Some papers have studied the effects of the increase in housing prices on the consumption and welfare of separate groups such as young renters, young homeowners and old homeowners. In particular, Campbell and Cocco (2005), using UK micro-level data on real non-durable consumption growth and real housing price growth and controlling for other factors such as real income growth, real mortgage payments growth and real interest rate growth, found a significant positive correlation between housing price growth and consumption growth, especially for old homeowners and, still quite significant but less in magnitude, for young homeowners. However, one noteworthy conclusion drawn from data is that housing price appreciation nearly does not affect the consumption of young renters. This is contrary to what one might expect from direct wealth effects, since the young renters are the most borrowing-constrained group. If they plan to move to a new house later in life, housing price appreciation should lead them to cut non durable consumption to accumulate more money for housing purchase. Li and Yao (2004) developed a life-cycle model of housing choice to explore the effects of housing price shocks on household consumption and welfare. In their model the household faces both uninsurable labor income and house price risk and chooses both whether to rent a house or to own it and how much housing stock to acquire. The model also includes transaction costs connected with selling the house and financing housing with a fixed rate mortgage. This research demonstrates that for the population less than 40 years old a permanent increase in housing price implies welfare losses. In particular, young renters are strictly worse off since they do not participate in housing wealth gains and yet face higher costs of acquiring housing services in the future. Young homeowners are also made strictly worse off since, although the increase in housing prices relaxes their borrowing constraints, price appreciation implies a higher cost of acquiring a larger house in the future, an effect that is more significant for the young homeowners. Only for old homeowners (40 years or older) with shorter horizons does the gain from appreciation of their housing wealth dominate higher future housing costs and their non-durable consumption as well as welfare increases. 
Bajari et al (2005) study the aggregate effect of housing price changes on consumer welfare. They develop a new approach to measuring the changes in consumer welfare due to changes in the prices of owner-occupied housing. This approach defines welfare adjustment as the transfer required to keep expected discounted utility constant, given the change in housing prices. The authors claim that this measure is more accurate than the user cost employed in earlier studies since the user cost (defined as the marginal rate of substitution between housing and non-durable consumption) is entirely static while the welfare adjustment involves dynamics. In addition user cost fails to take into account the role of housing as an investment good. Using their measure of welfare adjustment, the authors show that, up to first order approximation, there is no change in aggregate welfare due to an increase in the price of the existing stock of housing. This result is based on a simple market clearing condition which implies that the losses of buyers are exactly compensated by the gains of sellers. This holds for both a deterministic version of the model where current states convey no information about future states, as well as for a stochastic one where the state follows a first order Markov chain.

Bajari et al (2005) abstract from rental markets and binding credit or borrowing constraints (it is assumed that agents are not credit-constrained). However, Li and Yao(2004) show that a positive price shock implies a net welfare loss for individuals aged less than 40. These are the households for whom a credit constraint is likely to be binding. As was shown in Li and Yao(2004), housing appreciation implies two kinds of effects for these individuals: 1) an increase in lifetime housing costs because of the necessity to buy a larger house in the future; 2) a benefit due to a relaxation of credit constraints (due to housing wealth gains) and thus the opportunity for better consumption smoothing. Thus, by abstracting from borrowing constraints, Bajari et al (2005) ignore the additional effect which housing price appreciation has on creditconstrained individuals. Taking this effect into account can change the result of their paper concerning aggregate welfare adjustment. This implies that modeling the binding credit constraints in Bajari's framework can be an interesting extension.

Before proceeding further it is important to justify the practical value of such an extension or, in other words, to show that the assumption of binding credit constraints is a reasonable approximation of the real economy. It is possible to find out if credit 
constraints bind in the actual economy by comparing the actual loan-to-value ratio(LTV) on mortgages (that is, the percentage of the value of the house which households actually borrow when purchasing the house) with the maximum loan-tovalue ratio allowed by regulations (maximum percentage of the value of the house which they can borrow). According to the Tsakaronis and Zhu (2004), the maximum loan-to-value ratio for conventional mortgages in the US is equal to $80 \%{ }^{1}$. Using data on actual loan-to-value ratios by state contained in the Monthly Interest Rate Survey of the Federal Housing Finance Board, the economy-wide average actual LTV was computed for years 1995-2004, which are the core years of interest. The computed LTVs are summarized in Table 1. The findings of Table 1 demonstrate that in the majority of those years actual loan-to-value ratios were close to the maximum loan-tovalue ratio, which implies that in the actual economy the majority of households were borrowing as much as they could. This finding provides support for studying the aggregate welfare effects of housing price appreciation under the assumption of binding credit constraints, which is the first research question I am going to address in my paper. This research question is further validated by the fact, that other welfare papers with credit constraints, while exploring the effects of housing price appreciation on the

\section{TABLE 1 Actual average loan to value ratios}

\begin{tabular}{|l|l|}
\hline Year & actual LTV \\
\hline 1995 & 79.9 \\
\hline 1996 & 79.0 \\
\hline 1997 & 79.4 \\
\hline 1998 & 78.9 \\
\hline 1999 & 79.2 \\
\hline 2000 & 77.9 \\
\hline 2001 & 78.2 \\
\hline 2002 & 75.1 \\
\hline 2003 & 77.5 \\
\hline 2004 & 77.9 \\
\hline
\end{tabular}

1 This maximum LTV as well as the data in Table1 refers to conventional (prime) single family mortgages. During the last decade rapidly growing sub-prime lending market has appeared in the US. Sub-prime mortgages usually have higher LTVs than conventional ones, since they are given to households unable to meet the usual down payment requirements. I don't explicitly consider sub-prime loans in this research since, although their share in total mortgages constantly grew between 1995-2004, even in 2004 the number of sub-prime mortgages didn't exceed $20 \%$ of the total mortgages (according to the US Federal Reserve Bank), which is a relatively low share. 
welfare of separate groups, don't study its effects on aggregate welfare.

The interaction between housing prices and borrowing or credit constraints has been recently studied in several other papers including Ortalo-Magne and $\operatorname{Rady}(2005)$, Iacoviello(2004) Iacoviello(2005), and Lehnert(2004). In particular, Ortalo-Magne and Rady(2005) proposed a life-cycle model of housing consumption with property ladder, credit constraint and two types of housing, namely "starter" homes and "trade-up" homes. They identified the critical role of marginal first-time buyers in housing market fluctuations. In other words, the volatility of first-time buyers' income and thus their ability to afford the down payment for a starter home can explain an observed "excessive" volatility of housing prices. The second contribution of the paper is even more noteworthy. The research identified channels by which changes in income can explain such salient features of the housing market as housing price overreaction, volatility of housing prices and a positive correlation between housing prices and the volume of transactions in the housing market. This channel relies primarily on the capital gains and losses for a starter home experienced by credit-constrained individuals. This conclusion confirms my intuition that binding credit constraints can play an important role in the housing market.

Two major forms of credit constraint have been used in the previous literature. One of the most widely used models of credit constraints is that of Kiyotaki and Moore (1997). The authors study how credit constraints interact with aggregate economic activity over the business cycle. In their paper they develop a dynamic model of an economy subject to credit constraints, in which lenders cannot force borrowers to repay the loans unless they are secured by certain assets. In this model borrowing is restricted so that the repayment of a loan in the next period does not exceed the next period value of the asset serving as collateral. Similar borrowing constraints have been used in the housing literature. In particular Iacaviello and Minneti(2003) impose a credit constraint on borrowing according to which borrowing is restricted so that the repayment for a loan in the next period does not exceed some fraction of the next period's expected value (in the monetary terms) of the housing stock. Also, Iacoviello (2004) models the borrowing constraint on entrepreneurs according to which the repayment of their debt should not exceed a fraction of the expected real value of their housing stock in the next period. A similar constraint is used in papers related to financial markets. For example, 
Aghion and Bachetta (2004) analyze the role of financial factors as a source of instability in small open economies and impose constraints on borrowing under which entrepreneurs can borrow only some fraction of their initial wealth, with this fraction measuring the extent of financial market imperfections. However in this paper the constraint is based on their current wealth, not on expected future wealth. Finally, quite recently, a more efficient form of credit constraint has been modeled in the literature related to sudden stops in emerging market economies. This is called a margin clause constraint. For example, Mendoza and Durdu (2004) in their research on sudden stops to capital inflows in emerging economies, develop an asset pricing model subject to collateral constraints or margin clause constraints under which the borrowing of a small open economy cannot exceed a fraction of the current market value of the economy's equity holdings. This type of contract is more effective and is widely used in international capital markets by investment banks and other lenders as a mechanism to manage default risk (Mendoza and Durdu (2004)). In contrast to the Kiyotaki-Moore constraint, the custody of collateral assets is transferred at the time of entering into a credit contract,(in the later form it is transferred only in the next period, which is why it limits borrowing to the value of the asset in the next period), and there is more flexibility and less risk for lenders since they can automatically make up shortfalls in the value of the collateral asset by liquidating it as soon as the price changes so that the value of the collateral is exactly equal to the debt. Use of either of these two forms will have somewhat different implications for aggregate welfare in my model. In my research I will analyze an economy with a margin clause constraint and then briefly mention result if using the Kiyotaki-Moore constraint in the same model. It is noteworthy to mention that in a model with a Kiyotaki-Moore type constraint, housing price appreciation implies an improvement in aggregate welfare only with the additional assumption that housing prices follow a random walk, while in the model with a margin clause constraint housing price appreciation positively affects aggregate welfare even in the simplest deterministic version.

In addition, in Bajari et al (2005) the housing prices are exogenous. In contrast I make the housing price endogenous and allow it to be determined by housing market equilibrium and to change due to supply and demand shocks. In modeling the supply side shock I rely primarily on Glaeser and Guyourko (2005). In this research the authors 
explore the reasons for recent substantial housing price appreciation. They claim that the change in prices can be better understood by looking not only at demand-side factors, as has been done, but also at supply-side factors. The main observation of this paper is that until the 1970s housing prices moved together with increased housing quality and rising construction costs, but since the 70's housing price growth has substantially exceeded the increase in construction costs and quality of housing. Using a simple model of regulatory approval they show that the increase in housing prices since the 70's reflects an increasing difficulty to obtaining regulatory approval for building houses, which is conditioned by changing judicial tastes, decreasing ability to bribe regulators, and stricter formal procedures due to better organized political pressure from existing old homeowners. Thus, in essence this paper proves that housing price appreciation was to a large extent driven by a decrease in the construction of new housing due to stricter regulation, which in turn constrained the aggregate supply of housing and made it scarce relative to rising demand. I incorporate this reasoning into my model by allowing housing supply to be dependent on the costs of getting a permit for building a house and by generating an endogenous supply shock because of increasing regulation costs. Besides analyzing the consequences of housing price appreciation driven by supply shocks I also use the theoretical model to explore the consequences of housing price appreciation driven by demand side shocks such as changes in the median household income and interest rates. Thus, in a version of the model with endogenous prices I address my second research question, namely what would be the effect of housing price appreciation in case of making the housing price endogenous. Finally, after identifying these pure effects I explore the implications of housing price appreciation in an economy with both endogenous prices and binding credit constraints. At the end of the paper I calculate the aggregate welfare adjustment resulting from the combination of demand and supply shocks observed in the US economy in 1995-2004, which is also quite non-standard exercise for the previous housing literature. The result implies that even in a model with endogenous housing prices under the given combination of shocks, housing price appreciation implies an improvement in aggregate welfare. 


\section{Model with exogenous housing price and credit constraints}

\subsection{Version with margin clause}

Consider an economy subject to credit constraints in which there are two goods: a composite consumption good $c$ and housing $h$ with relative price $q$. Also, there are riskfree assets in the form of bonds $b$. Households choose how many bonds to carry into next period $b_{t+l}\left(b_{t+l}\right.$ can be either positive or negative. In the latter case households are borrowers), how much housing consumption to carry into next period $h_{t+1}$, and how much to consume now $c_{t}$. A household's investment into housing is denoted by $x_{t}$, and investment in the risk-free asset (saving) is denoted by $s_{t}$. Households have real income $y_{t}$, and the interest rate paid for borrowing or received for investment in bonds is exogenous and given by $i_{t}$. Inflation is constant at the rate $\pi$. Adjustment of housing stock implies transaction costs which enter into the budget constraint as a separate expenditure $\left(f 1\left\{x_{t} \neq 0\right\}\right)$. In this version of the model, I abstract from depreciation of housing and new construction and assume that there is a fixed stock of housing traded between the agents. This assumption allows for separating the pure effect of credit constraints from the point of view of housing price appreciation. Given that the welfare change from investment into replacing depreciated stock is already calculated in Bajari et al (2005), it can be easily taken into account afterwards.

Households are credit-constrained in the sense that they can borrow only up to a certain amount to finance their housing investment. At first let's consider a deterministic version of the economy (as in Bajari et al (2005)) where the credit constraint has the form of a margin clause. Under this constraint households can borrow only up to some fraction of their current wealth. In my model, a household's current wealth consists of the current value of its housing stock which can be used as collateral. Thus, the credit constraint takes the form:

$b_{t+1} \geq-m \cdot q_{t} \cdot h_{t+1}$ i.e households can borrow only up to fraction $\mathrm{m}<1$ of the total value of their housing stock .

Now the household's problem can be formulated in the following way:

$$
\begin{aligned}
& V\left(h_{t}, b_{t}, q_{t}, y_{t}\right)=\max \left\{u\left(c_{t}, h_{t}\right)+\beta V\left(h_{t+1}, b_{t+1}, q_{t+1}, y_{t+1}\right)\right\} \\
& \left\{\mathbf{c}_{\mathbf{t}}, \mathbf{h}_{\mathrm{t}+1}, \mathbf{b}_{\mathrm{t}+1}\right\}
\end{aligned}
$$

s.t. 


$$
\begin{aligned}
& c_{t}+q_{t} \cdot x_{t}+s_{t}+f 1\left\{x_{t} \neq 0\right\}=y_{t}+i_{t} \cdot b_{t} \\
& b_{t+1}-b_{t}=s_{t}-\pi \cdot b_{t} \\
& h_{t+1}-h_{t}=x_{t} \\
& b_{t+1} \geq-m \cdot q_{t} \cdot h_{t+1}
\end{aligned}
$$

Besides the credit constraint which was discussed above, the optimization includes three additional constraints. One is the usual budget constraint equating total real income to total expenditures. The second constraint says that real savings should be equal to the difference between bondholding for the next period and the current bondholding net of inflation. The third says that each period's investment in housing should be equal to the difference between the next period's housing stock and the current housing stock.

Now, as in Bajari et al (2005), I derive the user cost and see how the existence of a binding credit constraint changes the results of the previous model. One can substitute the second, third and fourth constraints into the first one to simplify the maximization and obtain the following constraints:

$$
\begin{aligned}
& c_{t}=y_{t}+i_{t} \cdot b_{t}-q_{t} \cdot\left(h_{t+1}-h_{t}\right)-\left(b_{t+1}-(1-\pi) \cdot b_{t}\right)-f 1\left\{x_{t} \neq 0\right\} \\
& b_{t+1} \geq-m \cdot q_{t} \cdot h_{t+1}
\end{aligned}
$$

The first order and envelope conditions for this problem are given by:

$$
\begin{aligned}
& \frac{\partial u\left(c_{t}, h_{t}\right)}{\partial c_{t}}=\lambda_{t} \\
& -q_{t} \cdot \lambda_{t}+\beta \cdot \frac{\partial V\left(h_{t+1}, b_{t+1}, q_{t+1}, y_{t+1}\right)}{\partial h_{t+1}}+v_{t} \cdot m \cdot q_{t}=0 \\
& -\lambda_{t}+v_{t}+\beta \cdot \frac{\partial V\left(h_{t+1}, b_{t+1}, q_{t+1}, y_{t+1}\right)}{\partial b_{t+1}}=0 \\
& \frac{\partial V\left(h_{t}, b_{t}, q_{t}, y_{t}\right)}{\partial h_{t}}=\frac{\partial u\left(c_{t}, h_{t}\right)}{\partial h_{t}}+\lambda_{t} \cdot q_{t} \\
& \frac{\partial V\left(h_{t}, b_{t}, q_{t}, y_{t}\right)}{\partial b_{t}}=\lambda_{t} \cdot\left(i_{t}+(1-\pi)\right)
\end{aligned}
$$

where $v$ is the multiplier for the credit constraint and $\lambda$ is the multiplier for the budget constraint. 
The user cost of capital was first defined as the opportunity cost of investing into capital goods (Hall and Yorgenson(1967)). Later Dougherty and Van Order(1982) in their housing model defined the user cost as the marginal rate of substitution between housing consumption and other consumption. It is essentially the measure of the value of the bribe necessary to get homeowners to give up one unit of housing.

Combining the above equations yields:

$q_{t} \cdot \frac{\partial u\left(c_{t}, h_{t}\right)}{\partial c_{t}}+m \cdot q_{t} \cdot\left(\beta \cdot\left(\frac{\partial u\left(c_{t+1}, h_{t+1}\right)}{\partial c_{t+1}} \cdot\left(i_{t+1}+1-\pi\right)\right)-\frac{\partial u\left(c_{t} h_{t}\right)}{\partial c_{t}}\right)=\beta \cdot\left(\frac{\partial u\left(c_{t+1}, h_{t+1}\right)}{\partial h_{t+1}}+\frac{\partial u\left(c_{t+1}, h_{t+1}\right)}{\partial c_{t+1}} \cdot q_{t+1}\right)$

Shifting this equation one period back and expressing MRS I get:

$\frac{\partial u\left(c_{t}, h_{t}\right)}{\partial h_{t}} \div \frac{\partial u\left(c_{t}, h_{t}\right)}{\partial c_{t}}=m \cdot q_{t-1} \cdot\left(i_{t}-\pi-\frac{\Delta q_{t}}{m^{*} q_{t-1}}+\frac{m-1}{m}\right)+q_{t-1} \cdot(1-m) \cdot \frac{\partial u\left(c_{t-1}, h_{t-1}\right)}{\partial c_{t-1}} \div \beta \cdot \frac{\partial u\left(c_{t}, h_{t}\right)}{\partial c_{t}}$

Comparing this expression with the expression for user cost in the Bajari et al's paper I conclude that the imposition of credit constraints has an ambiguous effect on user cost. Since $m<1$, the first term in this expression is unambiguously lower than the analogous term in Bajari et al's paper. However, user cost in this model also includes an additional term which is positive and easy to quantify if one assumes, for example, a power utility function separable in housing and consumption. This term can be approximately interpreted as the inverse of the return on housing investment. Investing one unit more into housing at time $t-1$ requires a reduction in consumption by $\mathrm{q}_{\mathrm{t}-1}$, and each unit of lost consumption presupposes a loss equal to the marginal utility of consumption. However, in period t one gets additional consumption, since the increased housing stock implies the possibility of higher borrowing in period $t$ and therefore higher consumption. Thus, the expression in the denominator of the second term can be viewed as the benefit from investing into housing. The fraction $m$ is also present in this term since borrowing increases only by the fraction $\mathrm{m}$ for each unit of increase in the housing stock.

The user cost in the economy subject to a credit constraint can be either higher or lower than in the benchmark paper depending on parameters. However, the major conclusions about user cost are the same. In particular, the user cost of housing services or the opportunity cost of investing into housing increases with the interest rate and deflation (negative inflation) since the expected return on savings increases. Also when housing prices increase (housing appreciation), as is evident from the formula, $\Delta q_{t}$ 
increases and user cost falls. However, user cost can give a misleading picture of the change in aggregate welfare, since this measure fails to recognize that housing is not only a consumption good, but also an investment good which enters the asset portfolio. Also, user cost gives a measure of the bribe necessary to keep only the single period utility constant; that is, it is a static measure, while the welfare adjustment is dynamic. Consequently, following Bajari et al (2005) I derive the dynamic welfare adjustment for an economy subject to credit constraints.

In what follows I concentrate on analyzing an economy in which credit constraint is binding. The justification for this assumption was given in the introduction (see Table 1). I define welfare adjustment as compensation in the form of income necessary to keep a household indifferent between the new and old prices (to keep the value function constant holding fixed all other factors except income). In essence this means that welfare adjustment is the change in income necessary to keep life-time utility unchanged. Since this change in income is meant to compensate for the change in lifetime utility because of housing price appreciation, it should be converted into utility terms by multiplying it by the marginal utility of wealth which is equal to the Lagrange multiplier of the budget constraint.

The change in the value function because of a change in prices can be defined as:

$$
\Delta V=\frac{\partial V\left(h_{t}, b_{t}, q_{t}, y_{t}\right)}{\partial q_{t}} \cdot \Delta q_{t}+\frac{\partial V\left(h_{t}, b_{t}, q_{t}, y_{t}\right)}{\partial y_{t}} \cdot \Delta y_{t}
$$

From this expression I derive $\Delta \mathrm{y}_{\uparrow}$ such that the change in the value function equals zero. Following Bajari et al (2005) I apply an envelope theorem and first order approximation and study the household's behavior at the optimal point where the value function is time invariant.

Taking derivatives:

$$
\begin{aligned}
& \frac{\partial V\left(h_{t}, b_{t}, q_{t}, y_{t}\right)}{\partial y_{t}}=\frac{\partial u\left(c_{t}, h_{t}\right)}{\partial c_{t}} \\
& \frac{\partial V\left(h_{t}, b_{t}, q_{t}, y_{t}\right)}{\partial q_{t}}=\frac{\partial u\left(c_{t}, h_{t}\right)}{\partial c_{t}} \cdot \frac{\partial c_{t}}{\partial q_{t}}=\frac{\partial u\left(c_{t}, h_{t}\right)}{\partial c_{t}} \cdot\left(-x_{t}\right)+\frac{\partial u\left(c_{t}, h_{t}\right)}{\partial c_{t}} \cdot m \cdot h
\end{aligned}
$$


Thus in this economy, the effect of a price change on value function consists of two effects, a direct and an indirect one. When housing price appreciates, there is a decrease in consumption due to more expensive investment in housing. This is the direct effect reflected in the first term. This effect is realized for each unit of future housing investment, so the marginal utility of consumption is multiplied by the amount of investment. On the other hand, due to the increase in price, the borrowing constraint relaxes, allowing households to increase borrowing and thus increase current consumption. The benefit of relaxing the borrowing constraint is realized for each unit of present housing stock. Thus, the marginal utility of consumption is multiplied by the existing housing stock. And since borrowing can increase only by the fraction $m$ per each unit of housing price appreciation, the marginal utility of consumption is also multiplied by $m$. This is an indirect effect reflected in the second term.

Equating $\Delta \mathrm{V}$ to zero gives:

$$
\Delta V=\frac{\partial u\left(c_{t}, h_{t}\right)}{\partial c_{t}} \cdot\left(-x_{t}\right) \cdot \Delta q_{t}+\frac{\partial u\left(c_{t}, h_{t}\right)}{\partial c_{t}} \cdot m \cdot h \cdot \Delta q_{t}+\frac{\partial u\left(c_{t}, h_{t}\right)}{\partial c_{t}} \cdot \Delta y_{t}=0
$$

Solving for $\Delta \mathrm{y}_{\mathrm{t}}$ gives:

$$
\Delta y_{t}=x_{t} \cdot \Delta q_{t}-m \cdot h_{t+1} \cdot \Delta q_{t}
$$

which defines the individual welfare adjustment due to housing price appreciation ${ }^{2}$.

The aggregate welfare adjustment is defined as the sum of all individual welfare adjustments. Looking at the last equation one can see that, in general, in this model the aggregate welfare adjustment will be different from zero since, although the first term will sum up to zero in aggregate (in aggregate $x_{t}=0$ that is the buying and selling of the existing housing stock exactly compensate each other), the sum of second terms will not be zero.

The next section interprets and quantifies the final result.

\subsection{Welfare adjustment in the economy with exogenous price: Interpretation and quantification}

Before analyzing aggregate welfare adjustment let me comment briefly on the properties of individual welfare adjustment for each group and compare my findings 
with the existing literature. For convenience I will restate the formula for individual welfare adjustment in this version of the economy:

$$
\Delta y_{t}=x_{j, t} \cdot \Delta q_{t}-m \cdot h_{j, t+1} \cdot \Delta q_{t} \equiv(1-m) \cdot h_{j, t+1} \cdot \Delta q_{t}-h_{j, t} \cdot \Delta q_{t} \quad \text { for household } \mathrm{j}
$$

where $x_{j, t}$ is the investment of household $j$ into housing services and $h_{j}$ is its amount of housing stock. This is the welfare adjustment for the version with a margin clause constraint $^{2}$.

Looking at (7) it is easy to see that results on the individual level are similar to those of Li and Yao (2004). In particular, from the formula it is evident that there is a cut-off level of the ratio of housing stock chosen for the next period to the currently owned one, such that for the ratios lower than this level the second term dominates the first one and the household experiences a welfare improvement (according to my definition negative $\Delta y$ means improvement in welfare), while for the ratios higher than this level, the first term dominates the second one and the household experiences a welfare loss. This can be intuitively explained from the point of view of homeowner's age and stage in the life cycle. For the young homeowners who are at the beginning of their adult life currently owned housing stock is small and their desired size of housing is high relative to what they currently own. Consequently, some young homeowners with a low housing stock in this period but who would like to move to a relatively large house in the future will experience a welfare loss due to housing price appreciation. On the contrary, the older homeowners who are in the later stages of their life cycle accumulate substantial housing stock towards retirement and their desired housing stock for the subsequent years decreases, implying that the second term is likely to dominate the first, leading to an improvement in their welfare. It is also important to mention that in this model with binding credit constraints a relatively small fraction of households is going to experience welfare loss due to housing price appreciation. If one sets $m \equiv 0.8$ (a typical LTV for the US), it turns out that its desired optimal housing stock would have to be

\footnotetext{
${ }^{2}$ Using the same procedure a welfare adjustment can be derived from the model with Kiyotaki- Moore constraint. The crucial difference between margin clause and this constraint is that the next period's price rather than this period's price enters into credit constraint. Thus to get a change in the borrowing constraint and consequently nonzero change in aggregate welfare from the change in current price it is necessary to assume that future prices are affected by current prices through a stochastic process. Several empirical papers have demonstrated that housing prices follow random walk. Using random walk assumption and applying the same procedure to the model with a constraint of the form $\left(1+i_{t+1}\right) \cdot b_{t+1}=-m \cdot E_{t} q_{t+1} \cdot h_{t+1}$ I get the result: $\Delta y_{t}=x_{t} \cdot \Delta q_{t}-\frac{m \cdot h_{t+1} \cdot \Delta q_{t}}{\left(1+i_{t+1}\right)}$
} 
more than four times the currently owned level for the household to experience a welfare loss. A rather low down payment for the new house, which delays to the later periods the necessity to pay out most part of the increase in new home's value as well as the assumption of binding credit constraints which makes the benefit from relaxation of the credit constraint even more sizable are perhaps driving this result.

Comparing my result to Bajari et al (2005), I note two crucial differences. The first is that for all groups in my economy the possible welfare loss is lower (welfare gain is higher) than in benchmark paper since there is an additional beneficial effect of housing price appreciation due to the improved ability of those households subject to binding credit constraint to smooth consumption. The second feature is the fact that homeowners do get a certain benefit from housing price appreciation even without participating in housing transactions (when $\mathrm{x}_{\mathrm{j}, \mathrm{t}}=0$ ), which is quite consistent with evidence from reality. For instance, older homeowners can leave larger bequests or invest more in retirement accounts in the case of housing price appreciation even without selling their house, while younger homeowners can shift their investment to risky assets or can increase their consumption.

As was already mentioned, the aggregate welfare adjustment is equal to the sum over agents of individual adjustments defined by (7). Assumption of investment only into existing housing and summing up, the first term of the expression vanishes $\left(\boldsymbol{\Sigma}_{\mathbf{j}, \mathbf{t}}=\mathbf{0}\right.$, since housing investment is done through trade, so that the sale of a house by one agent is exactly compensated by the purchase of that house by another agent), thus leaving the following expression for the aggregate welfare adjustment:

$$
W_{t}=-m \cdot \sum_{j}\left(h_{j, t+1}\right) \cdot \Delta q_{t}
$$

It turns out that the aggregate welfare adjustment in this economy with exogenous housing prices and credit-constrained households is negative, implying that in aggregate less income is necessary to keep lifetime utility constant. That is, housing price appreciation in an economy subject to binding credit constraints actually implies an improvement of aggregate welfare. This result is still based on market clearing condition, since losses to the buyers of existing houses are compensated by gains to the sellers. However, everybody in the economy who possesses any housing equity is made better off by housing price appreciation due to the relaxation of credit constraints. Thus, this additional indirect effect on welfare, which is positive for everybody, implies 
welfare improvement in the aggregate, although on a disaggregated level there are still some people who are worse off. This finding can also explain why in certain years characterized by housing price appreciation developed countries experienced consumption growth or, in some cases, even a consumption boom (Campbell and $\operatorname{Cocco}(2004))$.

It is possible to quantify the result in (8) and compare it to the result of Bajari et al (2005). The result in (8) can be interpreted as the change in the market value of the total housing stock, or in other words the change in the aggregate nominal housing wealth, weighted by the loan-to-value ratio. The data on aggregate nominal housing wealth in the US can be obtained from several studies (such as Case, Quigley and Shiller (2001), Nothaft (2004), etc). However, when using it to quantify the result of this model, it is important to take into account two observations. Firstly, the model does not have the explicit choice of renting the house. Consequently only the change in the value of owner-occupied housing stock in the actual economy should be considered. Secondly, the effect of relaxing borrowing constraints reflected in (8) should in reality be experienced only by credit-constrained households who take out a mortgage when purchasing the house. Finally, since I consider the case with binding credit constraints, this result is true for the households having mortgages with a maximum LTV or a LTV close to it. I thus take the change in the total value of housing stock in the US and multiply it by the share of owner-occupied housing in the total housing stock, by the share of mortgage-financed owner-occupied housing in the total owner occupied housing stock and also by the share of mortgages with LTV $70-80 \%$ (the average LTV in this group is $78-79 \%$ ) in the total number of mortgages. To calculate the first two shares I use the American Housing Survey published by the US Census Bureau which reports the total number of housing units, total number of owner- occupied housing units and total number of mortgage-financed owner-occupied housing units in US. The last share is taken from thee Monthly Interest Rate Survey of the Federal Housing Finance Board. The yearly change in nominal housing wealth in the US is calculated from the data in Nothaft (2004). Again I set $m=0,8$. Given this information I can calculate the total change in aggregate welfare for 1995-2003, which were years of especially significant housing price appreciation. This change is then divided by the number of households in the US economy (obtained from Current Population Report of 
US Department of Commerce) to obtain per household change in aggregate welfare (in 2003 dollars) in the model with credit-constrained households. The results are displayed in Figure 2.

\section{FIGURE 2}

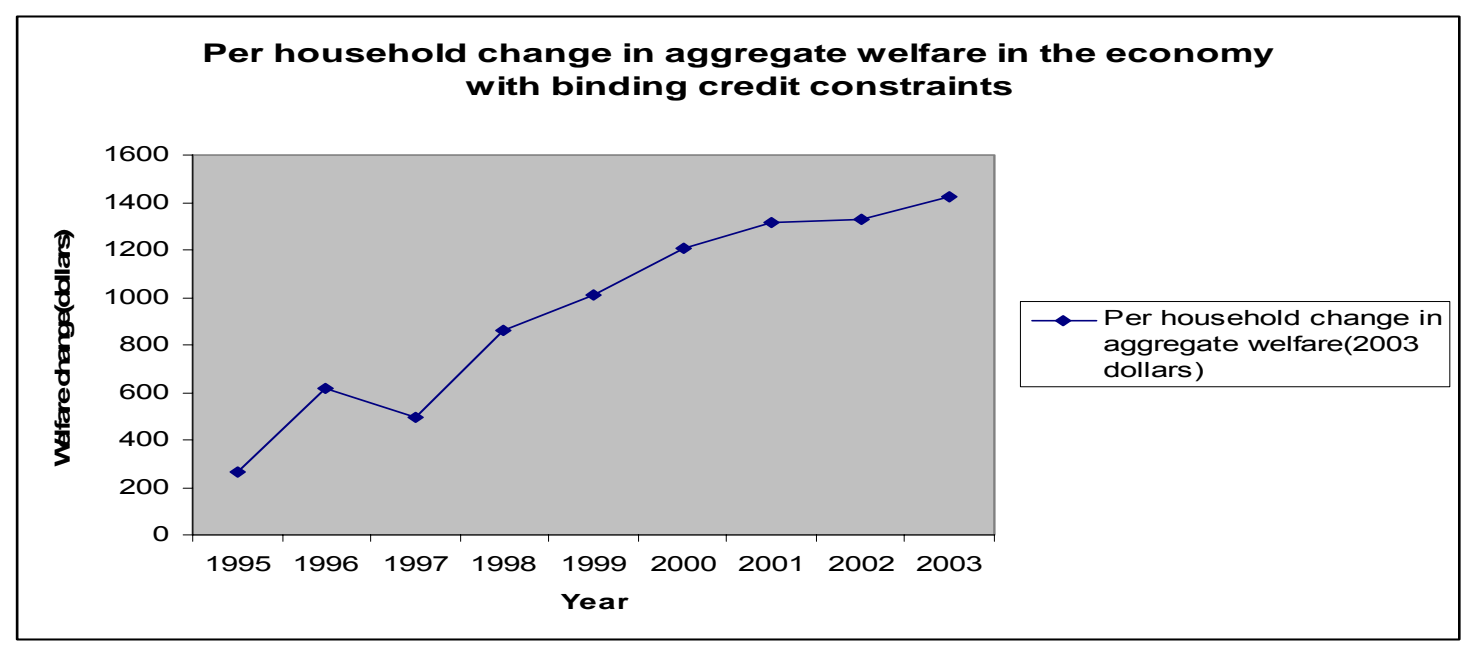

These results contrast sharply with those of Bajari et al (2005), who found no effects of housing price appreciation on aggregate welfare in case of investing in existing housing stock. It turns out that when accounting for binding credit constraints, the housing price appreciation which happened in the US between 1995 and 2003 improved aggregate welfare on average, by 947.8 dollars per household a year.

\section{Model with endogenous housing prices: Supply side shocks}

In this section I turn to analyzing a model with endogenous housing price defined by equilibrium demand and supply in the housing market. First I describe the demand side derived from the household sector, and then I incorporate competitive construction firms which are providing housing units. In this section I follow the assumption that households are not credit-constrained in order to observe the effect of endogenous housing price appreciation driven by the changes in supply side of the market. The economy with both endogenous housing price and credit constraints is analyzed in section 4. 


\subsection{Households}

The basic assumptions about the household sector in this model are analogous to the assumptions in section 2. The crucial difference is that the housing price is determined endogenously. Of course, this generates crucial differences in the equilibrium of these two economies. To be more realistic in this version I take into account physical depreciation of housing and assume that it occurs with constant rate $\delta$.

The household's problem in the economy with endogenous housing price can be formulated as follows:

$$
\begin{gathered}
V\left(h_{t}, b_{t}, y_{t}\right)=\max \left\{u\left(c_{t}, h_{t}\right)+\beta V\left(h_{t+1}, b_{t+1,} y_{t+1}\right)\right\} \\
\left\{\mathbf{c}_{t}, \mathbf{h}_{t+1}, \mathbf{b}_{t+1}\right\}
\end{gathered}
$$

s.t.

$$
\begin{aligned}
& c_{t}+q_{t} \cdot x_{t}+s_{t}+f 1\left\{x_{t} \neq 0\right\}=y_{t}+i_{t} \cdot b_{t} \\
& b_{t+1}-b_{t}=s_{t}-\pi \cdot b_{t} \\
& h_{t+1}-h_{t}=x_{t}-\delta \cdot h_{t}
\end{aligned}
$$

The F.O.C. for the household are analogous to those in Bajari's paper and are given by:

$$
\begin{aligned}
& \frac{\partial u\left(c_{t}, h_{t}\right)}{\partial c_{t}}-\lambda_{t}=0 \\
& -q_{t} \cdot \lambda_{t}+\beta \cdot \frac{\partial V\left(h_{t+1}, b_{t+1}, q_{t+1}, y_{t+1}\right)}{\partial h_{t+1}}=0 \\
& -\lambda_{t}+\beta \cdot \frac{\partial V\left(h_{t+1}, b_{t+1}, q_{t+1}, y_{t+1}\right)}{\partial b_{t+1}}=0 \\
& \frac{\partial V\left(h_{t}, b_{t}, q_{t}, y_{t}\right)}{\partial h_{t}}=\frac{\partial u\left(c_{t}, h_{t}\right)}{\partial h_{t}}+\lambda_{t} \cdot q_{t} \cdot(1-\delta) \\
& \frac{\partial V\left(h_{t}, b_{t}, q_{t}, y_{t}\right)}{\partial b_{t}}=\lambda_{t} \cdot\left(i_{t}+(1-\pi)\right)
\end{aligned}
$$

Substituting envelope conditions into the F.O.C., I derive the Euler equations for bondholding and housing consumption which are given by.

$\frac{\partial u\left(c_{t}, h_{t}\right)}{\partial c_{t}}=\beta \cdot \frac{\partial u\left(c_{t+1}, h_{t+1}\right)}{\partial c_{t+1}} \cdot\left(i_{t+1}+(1-\pi)\right)$ 
$q_{t} \cdot \frac{\partial u\left(c_{t}, h_{t}\right)}{\partial c_{t}}=\beta \cdot \frac{\partial u\left(c_{t+1}, h_{t+1}\right)}{\partial h_{t+1}}+\beta \cdot \frac{\partial u\left(c_{t+1}, h_{t+1}\right)}{\partial c_{t+1}} \cdot q_{t+1} \cdot(1-\delta)$

In the next section I describe the competitive construction sector, after which I will define the equilibrium solve for the steady state of the economy, and analyze the effects of endogenous housing price appreciation in the steady state.

\subsection{Construction firms}

In modeling supply shocks I rely on Glaiser and Guyourko (2005). Following their logic, a decrease in new construction is the crucial reason for housing price appreciation, so we assume a decrease in new construction due to an increase in regulation costs that generates an endogenous supply shock and drives housing prices up. In modeling the production of new housing I rely primarily on Amin and Capozza(1993)).

Let's assume that there is a perfectly competitive sector of construction firms that supply units to the housing market. The representative firm acts to maximize its profits taking the housing price as given. It has a production function given by $X_{s, t}=G\left(K_{t}, L_{t}\right)=K_{t}^{\alpha} \cdot L_{t}^{1-\alpha}$, where $K_{t}$ is the amount of capital used, $L_{t}$ is the amount land used and $\alpha<1$. I assume that firms face a constant returns to scale technology which implies a linear cost function with constant marginal cost, denoted by $d$. Output per unit of land is given by $x_{s, t}=g\left(k_{t}\right)=X_{s, t} / L=(K / L)^{\alpha}=\left(k_{t}\right)^{\alpha}$.Under these assumptions the total cost of production is given by $d \cdot k$. Construction firms need to obtain a permit from the zoning authority, a process that involves costs. The cost of each permit is given by $n$, which includes both cash expenditures needed to obtain the building permit as well as the cost of time necessary to obtain the building permit (in monetary terms). In real US economy regulation cost can vary either according to the value of the building project or according to the square footage of the constructed housing unit. I calibrate both the demand as well as the supply side of the model economy in terms of average housing unit, which will be defined later. Consequently I set the dollar value of the building permit cost according to the square footage of this typical unit. Under such calibration one building permit is necessary to build one unit of output, that is, one average housing unit ${ }^{3}$. Such an assumption is further justified by the fact that the entire 
US Census Bureau data on building permits is reported in terms new privately owned housing units authorized in permit-issuing places, rather than in terms of number of obtained building permits per se.

With these assumptions, I define the maximization problem of a construction firm as:

$\max \Pi=q_{t} \cdot x_{s, t}-d \cdot k_{t}-h_{s, t} \cdot n$

s.t. $x_{s, t}=\left(k_{t}\right)^{\alpha}$

The F.O.C for this problem are given by

$$
\alpha \cdot q_{t} \cdot\left(k_{t}\right)^{\alpha-1}-d-\alpha \cdot\left(k_{t}\right)^{\alpha-1} \cdot n=0
$$

From here one can get the optimal amount of input used by the construction firm, which is given by:

$$
k_{t}=\left(\frac{\alpha \cdot q_{t}-\alpha \cdot n}{d}\right)^{(1 /(1-\alpha))}
$$

This gives the optimal amount of capital/land ratio chosen by the representative firm. Substituting back into the production function, I get the amount of housing produced per unit of land, given by:

$$
x_{s, t}=g\left(k_{t}\right)=\left(\frac{\alpha \cdot q_{t}-\alpha \cdot n}{d}\right)^{(\alpha /(1-\alpha))}
$$

Moreover, since in equilibrium all the firms will act in the same way, multiplication of (17) by the aggregate stock of land will give the aggregate supply of new housing produced in equilibrium. It is evident from (17) that stricter regulation, which leads to an increase in the cost of obtaining a housing permit, immediately shifts the profit-maximizing input decision down and, thus, reduces the profit-maximizing output of the competitive firms per unit of land used. Thus, in equilibrium such an

\footnotetext{
${ }^{3}$ It is also possible to calibrate the economy in terms of square feet. If a square foot were considered a unit of output, one would need to define a parameter measuring the number of building permits used per square foot produced. This could be calculated using the data on number of square feet produced and number of building permits issued in the US during a typical year. However in this case it would be necessary to use housing price per square foot. A change in this price does not account for the quality adjustment, while constant quality price index for housing units does.
} 
increase leads to a decrease in the aggregate supply of new residential housing and endogenous housing price appreciation.

\subsection{Definition of equilibrium}

Let's define the aggregate supply of land as $\bar{L}$. It is reasonable to assume that the supply of land is fixed in the short run. Let's assume that there is an exogenous output of composite consumption good, given by $Y_{t}$. The supply side of the consumption good market is not modeled explicitly, since the analysis is focused on the housing market. Assume that there are $J$ households in the economy and $I$ firms. Under the assumption of representative firms and the assumption that factor markets clear, the aggregate supply of housing is given by:

$$
X_{t}=\sum_{i} g\left(k_{t}\right) \cdot L_{t i}=g(k) \cdot \bar{L}
$$

The equilibrium consists of prices $\mathrm{q}_{\mathrm{t}}$, interest rates $\mathrm{i}_{\mathrm{t}}$, allocations $\left\{\mathrm{c}_{\mathrm{t}}, \mathrm{h}_{\mathrm{t}+1}, \mathrm{~b}_{\mathrm{t}+1}\right\}$ by households and the profit maximizing input demand of firms $\mathrm{k}_{\mathrm{t}}$, such that:

1) given prices, households solve their optimization problem (conditions (14-(15))and firms maximize their profits (condition (17))

2) markets clear
i) $\sum_{j} x_{j, t}=X_{t}$
(housing market)
ii) $\sum_{j} c_{j, t}=Y_{t}$
(goods market)
iii) $b_{j, t+1}=0$
(bond market)

\subsection{Characterization of the welfare adjustment}

In this section I will derive the formula for welfare adjustment due to an endogenous housing price appreciation for an economy in a steady state. The full derivation of steady state for this economy is given in the appendix.

Suppose that the economy is in a steady state when regulation costs reflected in $n$ increase, driving up the price of housing. Since this is a negative supply-side shock, intuitively the new steady state will be characterized by lower aggregate housing stock, 
a welfare decreasing effect. The consumption of the composite good can also change since, as a result of the increase in the equilibrium housing price, homeowners experience capital gains on their current housing stock and also substitute from more expensive housing to a relatively cheaper composite good. However, a negative supplyside shock should eventually lead to a decrease in the aggregate welfare. In this section I consider a model with a Cobb-Douglas utility function, which is fully analytically solvable, but where steady state consumption does not explicitly depend on the housing price (see the appendix) since the income and substitution effects on consumption exactly cancel each other. After analyzing this simpler case from the point of view of supply-side driven and demand-side driven housing price changes, I analyze the case with more general power- separable utility where the change in housing prices causes a change not only in housing consumption but also in composite good consumption. Similar to Section 2, I define the welfare adjustment as the change in income necessary to keep lifetime utility constant when $\mathbf{n}$ increases. In the case of a first-order approximation this can be written as:

$$
\Delta V=\frac{\partial V(h, b, y)}{\partial n} \cdot \Delta n+\frac{\partial V(h, b, y)}{\partial y} \cdot \Delta y=\frac{\partial V(h, b, y)}{\partial h} \cdot \frac{\partial h}{\partial q} \cdot \frac{\partial q}{\partial n} \cdot \Delta n+\frac{\partial V}{\partial c}\left(\frac{\partial c}{\partial q}+\frac{\partial c}{\partial h} \cdot \frac{\partial h}{\partial q}\right) \cdot \frac{\partial q}{\partial n} \cdot \Delta n+\frac{\partial V}{\partial y} \cdot \Delta y
$$

Taking derivatives gives:

$$
\begin{aligned}
& \frac{\partial V(h, b, y)}{\partial n}=\frac{\partial u\left(c^{s s}, h^{s s}\right)}{\partial h^{s s}} \cdot \frac{\partial h^{s s}}{\partial q^{s s}} \cdot \frac{d q^{s s}}{d n}=\frac{\partial u\left(c^{s s}, h^{s s}\right)}{\partial h^{s s}} \cdot\left(-\frac{\omega \cdot\left(y^{s s}-f 1\left\{x^{s s} \neq 0\right\}\right)}{A \cdot\left(q^{s s}\right)^{2}}\right) \cdot\left(\frac{\alpha^{2} \cdot q^{s s} \cdot n}{\alpha \cdot q^{s s}-\alpha \cdot n \cdot(1-\alpha)}\right) \\
& \frac{\partial V(h, b, y)}{\partial y}=\frac{\partial u\left(c^{s s}, h^{s s}\right)}{\partial c}
\end{aligned}
$$

Substituting the last two equations into the formula for $\Delta \mathrm{V}$, equating it to zero, using the fact that the second term is zero and using utility form (32) (see appendix) and steady state ratio of consumption over housing expressed from (20)(see appendix), I get:

$$
\Delta y=\Delta n \cdot \omega \cdot\left(i^{s s}+\delta-\pi\right) \cdot\left(\frac{y^{s s}-f 1\left\{x^{s s} \neq 0\right\}}{A}\right) \cdot\left(\frac{\alpha}{q^{s s}-n \cdot(1-\alpha)}\right)
$$

This welfare adjustment for an economy with endogenous housing will be signed and discussed in Section 5. 


\section{The model with endogenous housing price and credit constraints}

\subsection{Households}

Now in addition to endogenous housing prices, households face credit constraints analogous to those of Section 2.

The household's optimization problem is given by:

$$
V\left(h_{t}, b_{t}, y_{t}\right)=\max _{\left\{\mathbf{s}_{t}, \mathbf{h}_{t+1}, \mathbf{b}_{t+1}\right\}}\left\{\left(c_{t}, h_{t}\right)+\beta \cdot V\left(h_{t+1}, b_{t+1}, y_{t+1}\right)\right\}
$$

s.t.

$c_{t}+q_{t} \cdot x_{t}+s+f 1\left\{x_{t} \neq 0\right\}=y_{t}+i_{t} \cdot b_{t}$

$b_{t+1}-b_{t}=s_{t}-\pi \cdot b_{t}$

$h_{t+1}-h_{t}=x_{t}-\delta \cdot h_{t}$

$b_{t+1} \geq-m \cdot q_{t} \cdot h_{t+1}$

The F.O.C. and envelope conditions are given by:

$\frac{\partial u\left(c_{t}, h_{t}\right)}{\partial c_{t}}-\lambda_{t}=0$

$-q_{t} \cdot \lambda_{t}+\beta \cdot \frac{\partial V\left(h_{t+1}, b_{t+1}, q_{t+1}, y_{t+1}\right)}{\partial h_{t+1}}+v_{t} \cdot m \cdot q_{t}=0$

$-\lambda_{t}+v_{t}+\beta \cdot \frac{\partial V\left(h_{t+1}, b_{t+1}, q_{t+1}, y_{t+1}\right)}{\partial b_{t+1}}=0$

$\frac{\partial V\left(h_{t}, b_{t}, q_{t}, y_{t}\right)}{\partial h_{t}}=\frac{\partial u\left(c_{t}, h_{t}\right)}{\partial h_{t}}+\lambda_{t} \cdot q_{t} \cdot(1-\delta)$

$\frac{\partial V\left(h_{t}, b_{t}, q_{t}, y_{t}\right)}{\partial b_{t}}=\lambda_{t} \cdot\left(i_{t}+(1-\pi)\right)$

Euler equations of this model are given by

$v_{t}=\frac{\partial u\left(c_{t}, h_{t}\right)}{\partial c_{t}}-\beta \cdot \frac{\partial u\left(c_{t+1}, h_{t+1}\right)}{\partial c_{t+1}} \cdot\left(i_{t+1}+1-\pi\right)$

$q_{t} \cdot \frac{\partial u\left(c_{t}, h_{t}\right)}{\partial c_{t}}=\beta \cdot \frac{\partial u\left(c_{t+1}, h_{t+1}\right)}{\partial h_{t+1}}+\beta \cdot \frac{\partial u\left(c_{t+1}, h_{t+1}\right)}{\partial c_{t+1}} \cdot q_{t+1} \cdot(1-\delta)+m \cdot q_{t} \cdot\left(\frac{\partial u\left(h_{t}, c_{t}\right)}{\partial c_{t}}-\beta \cdot \frac{\partial u\left(c_{t+1}, h_{t+1}\right)}{\partial c_{t+1}} \cdot\left(i_{t+1}+1-\pi\right)\right)$ 


\subsection{Construction firms}

All the assumptions about construction firms remain unchanged from section 3 .

\subsection{Definition of equilibrium}

The definition of equilibrium is also analogous to that of the previous section except that the equilibrium in the bond market changes. I concentrate my analysis on the situation in which credit constraint is binding. This implies that households are net borrowers, with the amount of borrowing determined endogenously depending on the amount of housing consumption chosen. I do not explicitly model the equilibrium in the credit market since I am not interested in the behavior of the interest rate. Concentrating on the housing market, I assume that there is an exogenously given supply of borrowing funds by banks denoted by $B$. Thus the equilibrium on the credit market requires that:

iii) $\sum_{j} b_{j, t+1}=B$

The rest of the definition of equilibrium is the same.

\subsection{Characterization of welfare adjustment}

Now let's turn to the effects of endogenous price appreciation in this economy. Again I analyze the economy in the steady state, characterization of which is provided in the appendix. The supply side of the economy is unchanged from the previous version of the model, and since only the supply side directly reacts to changes in regulation cost it is reasonable to expect housing price changes of the same magnitude due to increase in regulation costs. Thus, the derivative of $q$ over $n$ is unchanged.

In this version of the economy the general welfare adjustment is defined by the following:

$$
\Delta V=\frac{\partial V(h, b, y)}{\partial h} \cdot \frac{\partial h}{\partial q} \cdot \frac{\partial q}{\partial n}+\frac{\partial V}{\partial c}\left(\frac{\partial c}{\partial q}+\frac{\partial c}{\partial h} \cdot \frac{\partial h}{\partial q}\right) \cdot \frac{\partial q}{\partial n} \cdot \Delta n+\frac{\partial V}{\partial c} \cdot \frac{\partial c}{\partial b} \cdot\left(\frac{\partial b}{\partial q}+\frac{\partial b}{\partial h} \cdot \frac{\partial h}{\partial q}\right) \cdot \frac{\partial q}{\partial n} \cdot \Delta n+\frac{\partial V}{\partial y} \cdot \Delta y
$$

Performing similar manipulations as in section 3.4 and canceling out 2nd and 3rd terms (as you can see in the appendix neither steady state borrowing nor consumption explicitly depend on housing price), I produce the formula for individual welfare 
adjustment in the economy with both credit constraints and endogenous housing price:

$\Delta y=\Delta n \cdot \omega \cdot \frac{\alpha}{q^{s s}-n \cdot(1-\alpha)} \cdot\left(\frac{B}{\beta} \cdot \frac{1}{1-\omega} \cdot\left(\frac{y^{s s}-f 1\left\{x^{s s} \neq 0\right\}}{D}\right)\right)$

where $B$ and $D$ are constants given in the appendix.

\section{Welfare adjustment in economies with endogenous housing prices and supply side shocks: Interpretation and comparison}

Now let's sign and compare the welfare adjustments in the economies with endogenous housing prices driven by supply-side shocks.

The result in an economy with an endogenous housing price but without credit constraints is given by:

$\Delta y=\Delta n \cdot \omega \cdot\left(i^{s s}+\delta-\pi\right) \cdot\left(\frac{y^{s s}-f 1\left\{x^{s s} \neq 0\right\}}{A}\right) \cdot\left(\frac{\alpha}{q^{s s}-n \cdot(1-\alpha)}\right)$

where $A=(1-\omega) \cdot i^{s s}+\omega \cdot \pi+\delta-\pi$ and $\alpha<1$

Looking at (33) (in the appendix) and taking into account that the housing stock cannot be negative and that transactions costs for housing cannot exceed income, it is evident that $A$ should be positive. The straightforward question is whether such assumptions correspond to the real values of the relevant parameters. Earlier studies such as Margolis(1982) and Malpezi and Ozane(1987) have estimated gross depreciation rate of $2 \%$ for the housing stock in the USA. More recent studies such as Kostenbauer(2001) have come up with an estimates of $1.5-1.7 \%$, but this rate is for Canada. Also at the end of the 1980s and beginning of the 1990s the Congress raised the depreciation period for housing in the US to 27.5 years, which implies a yearly depreciation rate of around $3.5 \%$. Based on this range of estimates I set $\delta=0.025$. Based on International Financial Statistics published by the IMF I assume $\pi=0.02$ and $i=0.0402$ (these are current values for inflation and nominal interest rate on long term government bonds in the US). Using $\omega=0.56$ (I will elaborate on the calibration of this parameter later in this section) I get $A=0.0338$, which implies that the second and third terms in this multiplication are positive. The fourth term is positive since it comes from the effect of the increase in regulation costs on housing prices, which must be strictly positive. Change in $n$ is 
positive by assumption. Consequently the individual welfare adjustment in this model is positive. Thus in an economy with endogenous housing prices where households are not credit-constrained, the housing price appreciation driven by negative supply side shock leads to a welfare loss.

In a model with both credit constraints and endogenous housing prices, the welfare adjustment is given by:

$$
\Delta y=\Delta n \cdot \omega \cdot \frac{\alpha}{q^{s s}-n \cdot(1-\alpha)} \cdot\left(\frac{B}{\beta} \cdot \frac{1}{1-\omega} \cdot\left(\frac{y^{s s}-f 1\left\{x^{s s} \neq 0\right\}}{D}\right)\right)
$$

where $B=1-\beta \cdot(1-\delta)-m\left(1-\beta \cdot\left(i^{s s}+1-\pi\right)\right)$ and $\mathrm{D}=\frac{1-\omega}{\omega \cdot \beta} \cdot B-m \cdot \pi+i^{s s} \cdot m+\delta$

From (41) (in the appendix) it is easy to see that positive consumption requires $B>0$ if $\omega<1$. From (42) (in the appendix) D should also be greater than zero. Consequently, in this economy the welfare adjustment is positive, implying that when endogenous housing price appreciation is driven by negative supply shocks and preferences are of Cobb-Douglas form, agents experience a welfare loss both with and without credit constraints.

One can compare the last two formulas for welfare adjustments to establish whether credit constraints alleviate or exacerbate the welfare loss from a negative supply shock. For simplicity let's abstract from fixed transaction costs; that is let's assume that $f 1\left\{x^{s s} \neq 0\right\} \equiv 0$. Also, to make a fair comparison I ignore the possible difference between income of credit-constrained and unconstrained households and assume the same income for both economies ${ }^{4}$. Examining (19) and (20) it is evident that for comparing those two adjustments one should compare the terms $\frac{i^{s s}+\delta-\pi}{A}$ and $\frac{B}{\beta \cdot(1-\omega) \cdot D}$. It is possible to calculate these terms by setting concrete values for parameters. In both economies I set $\pi=0.02$. For a credit-constrained economy I set $i^{s s, c}=0.057$, which was the level of the average effective interest rate on mortgages in US in 2004 (obtained from Monthly Interest Rate Survey of Federal Housing Finance Board). For the unconstrained economy, as a proxy for the nominal interest rate I take 
the nominal yield on long-term government bonds, setting $i^{s s, u c}=0.0402$. Finally, since in my analysis I am considering an economy with binding credit constraints, the Lagrange multiplier of the credit constraint is positive, that is $v^{\text {ss }}>0$. Mathematically, the discount factor for the economy with binding credit constraints is given by:

$\beta^{\prime}=\frac{1-v^{s s} / \frac{\partial u\left(c^{s s}, h^{s s}\right)}{\partial c^{s s}}}{i^{s s}+(1-\pi)}$

while the discount factor for the economy without credit constraints is given by

$\beta=\frac{1}{i^{s s}+(1-\pi)}$

Looking at the last two expressions and taking into account that $v^{\text {ss }}>0$ and that the interest rate is higher in the economy with binding credit constraints, it is evident that the discount factor in this economy should be lower than the discount factor in the unconstrained economy. Thus, for the economy with binding credit constraints I set $\beta=0.96$, which is somewhat lower than the conventional $0.98-0.99$. Finally $\mathrm{I}$ set $\mathrm{m}=0.8$ based on Table 1. Using all these values I perform a sensitivity analysis by computing both terms mentioned above for values of preference parameter $\omega$ ranging from 0.1 to 0.9. The results are presented in Table 2 .

TABLE 2 Comparison of welfare adjustments in constrained and unconstrained models

\begin{tabular}{|c|c|c|}
\hline$\omega$ & Unconstrained & Constrained \\
\hline & $i^{s s}+\delta-\pi$ & $B$ \\
\hline & $A$ & $\beta \cdot(1-\omega) \cdot D$ \\
\hline 0.1 & 1.046781 & 0.121252 \\
\hline 0.2 & 1.098154 & 0.274385 \\
\hline 0.3 & 1.154829 & 0.473092 \\
\hline 0.4 & 1.217672 & 0.740199 \\
\hline 0.5 & 1.287749 & 1.11679 \\
\hline 0.6 & 1.366385 & 1.685037 \\
\hline 0.7 & 1.455248 & 2.636675 \\
\hline 0.8 & 1.556474 & 4.546914 \\
\hline 0.9 & 1.672835 & 8.291815 \\
\hline
\end{tabular}

The table demonstrates that the welfare adjustment required by a housing price appreciation due to an increase in regulation costs is lower in a credit-constrained

\footnotetext{
${ }^{4}$ In case of accounting for income differences, as I did in earlier drafts of the paper, the results of comparison are practically the same as in this draft.
} 
economy than in an unconstrained economy for all $\omega \leq 0.5$ but is higher in the constrained economy than in the unconstrained economy for all $\omega \geq 0.6$. Thus, the relationship between the welfare changes in credit-constrained and unconstrained economies depends on the relative weight of housing in the agent's utility function. When $\omega \geq 0.6$, the housing consumption is more important to households than consumption of the composite good. Since credit-constrained households intuitively have a lower housing stock than unconstrained ones, the marginal utility of housing for them is higher. Consequently when housing consumption has a relatively high weight in the utility function credit, constrained households loose more from a decrease in their steady state housing stock which has higher marginal utility for them, than credit unconstrained households.

It is possible to calculate $\omega$ using shares of housing and non-durable consumption in average annual expenditures in the US economy. According to the Consumer Expenditures Survey published by Bureau of Labor Statistics the share of housing in the expenditures in 2004 was equal to $32.1 \%$ and the share of non-durable consumption (aggregated from separate components given in the Consumption Expenditure Survey) was equal to $49 \%$. On the other hand in my model the dollar value of one period expenditures on composite good (non-durable consumption) is given by $c^{s s}$ (since the price of consumption is normalized at 1) and the dollar value of one period expenditures on housing is given by $\delta \cdot q^{s s} \cdot h^{s s}$ ( since during one period households consume value of the depreciated housing stock). Looking at the steady state allocations in the appendix it is easy to see that in both credit-constrained and unconstrained versions of the economy the ratio $\frac{c^{s s}}{\delta \cdot q^{s s} \cdot h^{s s}}$ is a function of $\omega$ only and the other already calibrated parameters.

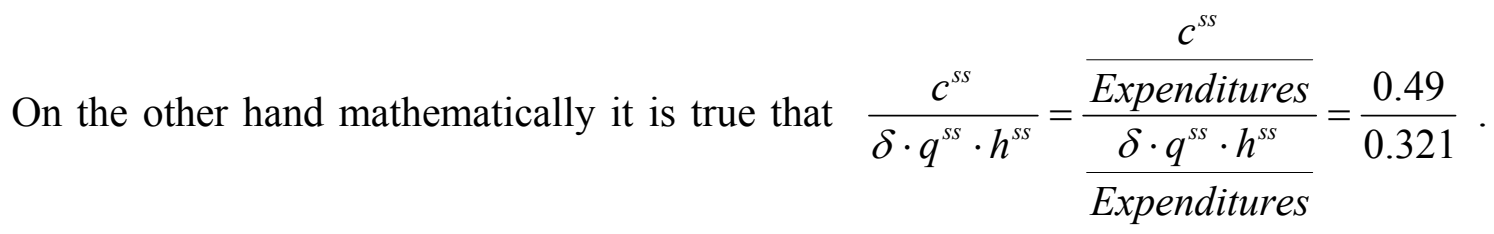
Thus, $\omega$ can be calculated from this equation. For defining the plausible range of values for $\omega$ at first I treat all the households in a real economy as unconstrained using steady state allocations from unconstrained model and calculate $\omega$ from the above equation. I 
then treat all the households as credit-constrained using allocations from constrained model and again calculate $\omega$.

The unconstrained model gives:

$$
\frac{c^{s s}}{\delta \cdot q^{s s} \cdot h^{s s}}=\frac{(1-\omega) \cdot\left(i^{s s}+\delta-\pi\right)}{\omega \cdot \delta}=\frac{0.49}{0.321}
$$

from which $\omega=0.56$.

Constrained model gives

$\frac{c^{s s}}{\delta \cdot q^{s s} \cdot h^{s s}}=\frac{B \cdot(1-\omega)}{\omega \cdot \beta \cdot \delta}=\frac{0.49}{0.321}$

from which $\omega=0.64$. Since there are both types of households in the real economy, the true value of $\omega$ should be between 0.56 and 0.64 . Finally, in the case of $\omega=0.56$ the adjustment in constrained model is only marginally higher than that in the unconstrained economy since $\frac{i^{s s}+\delta-\pi}{A}=1.33380$ and $\frac{B}{\beta \cdot(1-\omega) \cdot D}=1.37297$, while in case of $\omega=0.64$, credit-constrained households clearly loose more from negative supply shock since $\quad \frac{i^{s s}+\delta-\pi}{A}=1.672835$ and $\frac{B}{\beta \cdot(1-\omega) \cdot D}=2.00179$

\section{Model with endogenous housing price: Demand side shocks}

Up to this point the analysis with endogenous housing price was concentrated on the supply side of the market. Undoubtedly shifts in the supply side of the housing market have been the crucial reasons of observed housing price appreciation. However, an analysis of the welfare effects of housing price appreciation would not be complete without also looking at the demand side of the market. From the perspective of exploring the welfare effects of housing price changes, a distinction between the supplyside shocks and demand- side shocks is especially important. While having the same ultimate result, an increase in housing prices, a positive demand-side shock intuitively should have quite different implications for the welfare than a negative supply-side shock. Inspection of the actual US data on mortgages and incomes identifies changes in household income and interest rates as the most probable demand-side shocks 
contributing to the observed housing price appreciation during the last decade. Using the same theoretical model as in the previous sections, this section spells out the implications of the changes in demand-side factors on the aggregate welfare.

\subsection{Shifts in income as the reason for housing price appreciation}

In general, changes in income constitute the most natural demand-side shock in any market including the housing market. Consequently, when searching for demandside shocks affecting housing prices I first look at the dynamics of income in the US during the years of housing price appreciation. Annual figures for median household income in the US, obtained from the Current Population Survey are presented in Figure 3 together with constant quality housing price index displayed previously in Figure 1.

The graph clearly shows that years of substantial housing price appreciation were characterized by a considerable upward shift in the median household income which, after staying nearly constant in the first half of the 90's began to grow rapidly in second half. Calculating the growth rate of income from US Census Bureau data indicates that in 1988-1994 median household income increased by only $17.7 \%$ while in $1995-2001$ it grew by $24.5 \%$. Empirical evidence would thus suggest that changes in income were an important demand-side driver of housing price appreciation in the last decade.

FIGURE 3

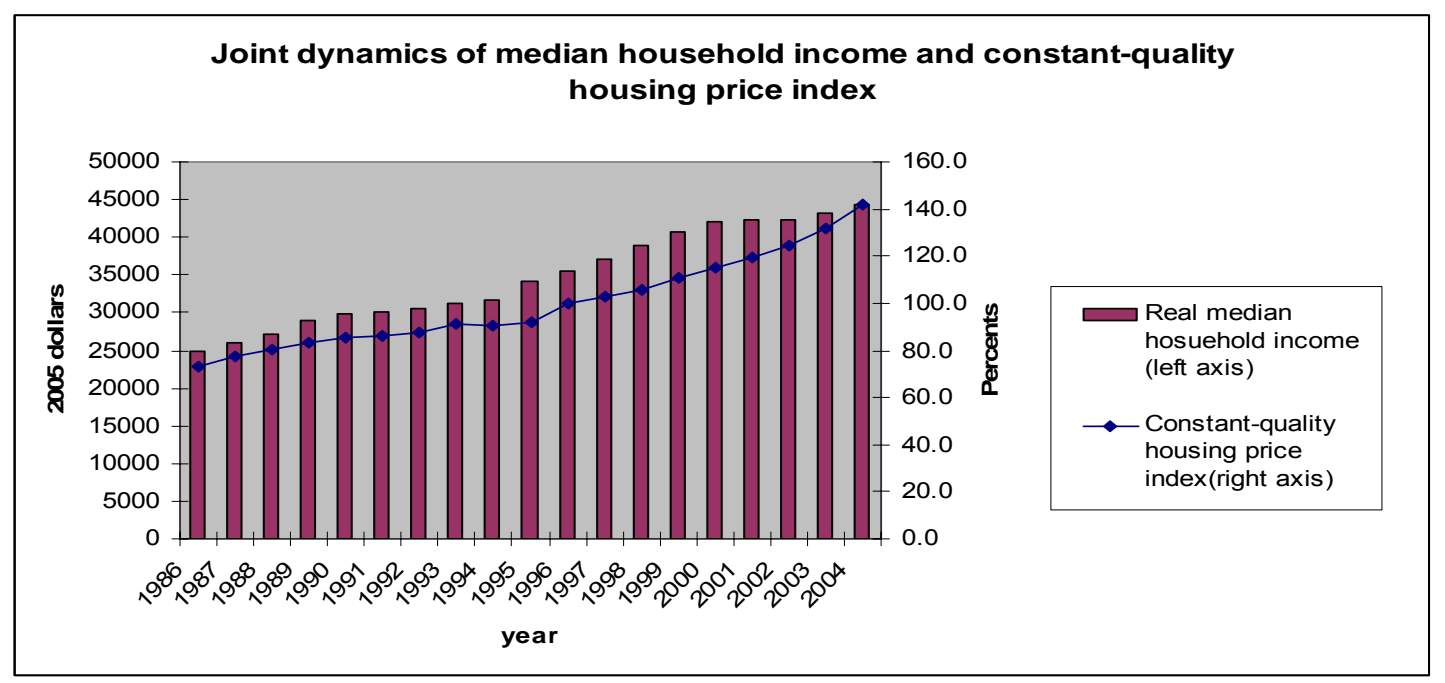

- Source: US Census Bureau 
Now, using my theoretical model I turn to analyzing what this change in income implies for welfare. In general positive income shocks should generate an increase in steady state consumption and housing consumption, but they also lead to housing price appreciation through increased demand, which decreases housing consumption after the initial increase. Thus housing is subject to positive income and negative substitution effects. However, housing is a normal good and thus in the new steady state housing consumption should remain on the higher level. Consequently, the total welfare should increase as a result of housing price appreciation driven by positive income shocks.

Let's denote by $\Delta y_{n}$ the new change in income that is the welfare adjustment and by $\Delta y_{\text {old }}$ the initial change in income that is the shock. The welfare adjustment is derived from the following equation:

$$
\Delta V=\frac{\partial V}{\partial c} \cdot \frac{\partial c}{\partial y} \cdot \Delta y_{o}+\frac{\partial V}{\partial h}\left(\frac{\partial h}{\partial y}+\frac{\partial h}{\partial q} \cdot \frac{\partial q}{\partial y}\right) \cdot \Delta y_{o}+\frac{\partial V}{\partial y} \cdot \Delta y_{n}=0
$$

This equation can be used to derive the welfare adjustment both for the economy subject to credit constraints as well as the unconstrained economy. I will need both of them when calculating aggregate welfare adjustment, which happened in the actual economy in 1995-2004. Using the steady state derived in the appendix, taking derivatives, and substituting into the above equation yields the following result in case of unconstrained economy:

$$
\Delta y_{n}=-\frac{(1-\omega) \cdot\left(i^{s s}+\delta-\pi\right)}{A} \cdot \Delta y_{o}-\left(i^{s s}+\delta-\pi\right) \cdot\left(\frac{\omega}{A}-\frac{\omega \cdot\left(y^{s s}-f 1\left\{x_{s s} \neq 0\right\}\right)}{A \cdot q^{s s}} \cdot \frac{\partial q}{\partial y}\right) \cdot \Delta y_{o}
$$

where

$$
\frac{\partial q}{\partial y}=\frac{J \cdot \delta \cdot \omega \cdot d^{\alpha /(1-\alpha)}}{A \cdot q^{s s} \cdot \bar{L} \cdot \frac{\alpha^{2}}{1-\alpha} \cdot\left(\alpha \cdot q_{s s}-\alpha \cdot n\right)^{\frac{\alpha}{1-\alpha}-1}+A \cdot \bar{L} \cdot\left(\alpha \cdot q^{s s}-\alpha \cdot n\right)^{\frac{\alpha}{1-\alpha}}} \succ 0
$$

The last equation was obtained as in previous cases by applying an implicit function theorem to the housing market clearing condition derived in the appendix. The second term of welfare adjustment given above is the final change in housing stock due to income and substitution effect.

The welfare adjustment in an economy with binding credit constraints is given by:

$$
\Delta y_{n c}=-\frac{B \cdot(1-\omega)}{\omega \cdot \beta \cdot D} \cdot \Delta y_{o}-\frac{B}{\beta} \cdot\left(\frac{1}{D}-\frac{y^{s s}-f 1\left\{x_{s s} \neq 0\right\}}{D \cdot q^{s s}} \cdot \frac{\partial q}{\partial y}\right) \cdot \Delta y_{o}
$$


where

$$
\frac{\partial q}{\partial y}=\frac{J \cdot \delta \cdot(d)^{\alpha /(1-\alpha)}}{q^{s s} \cdot \bar{L} \cdot D \cdot \frac{\alpha^{2}}{1-\alpha} \cdot\left(\alpha \cdot q_{s s}-\alpha \cdot n\right)^{\frac{\alpha}{1-\alpha}-1}+\bar{L} \cdot D \cdot\left(\alpha \cdot q^{s s}-\alpha \cdot n\right)^{\frac{\alpha}{1-\alpha}}}>0
$$

and $\mathrm{B}$ and $\mathrm{D}$ are constants given in the appendix.

At this moment the sign of the last two results is ambiguous since the second term in both expressions is not necessarily negative. Intuitively it should negative since in the case of housing the income effect usually dominates the substitution effect. I will quantify these results in Section 7 when calculating actual welfare adjustments.

\subsection{Changes in interest rates as the reason for housing price appreciation}

From my theoretical model one can see that a positive demand-side shock can also be generated by changes in interest rates. One of the obvious channels positively affecting the housing demand of credit-constrained individuals is the decline in mortgage interest rates. For the credit-constrained individuals who are net borrowers, a decrease in the mortgage rate implies lower current payments for their mortgages. This increases their disposable income, which in turn means that they can increase housing consumption and/or consumption of the composite good. Those who are not creditconstrained can be either borrowers or lenders depending on the interest rates. For the people who are net lenders, housing and bonds can be considered alternative investment opportunities or assets. Consequently, if unconstrained households who are net lenders observe a decline in the interest rates on bonds, for them housing becomes a more attractive investment relative to bonds and they shift investments towards housing, thus further raising housing demand. Finally, unconstrained individuals who are net borrowers will have an incentive to borrow when faced with lower interest rates. This allows them to increase their current housing stock, which again stimulates total demand. In summary a decrease in mortgage interest rates and nominal interest rates on bonds generates an increase in the housing demand for both credit-constrained and unconstrained households.

At this point, one should ask what happened to the nominal interest rates on bonds and mortgage interest rates in the real economy in 1990's. The evolution of the average 
effective interest rates on mortgages and long term government bond yields in the US from 1985 to 2003 is summarized in Figure 4 and Figure 5 respectively.

The figures clearly demonstrate a downward trend in the interest rates both in the 1995-2003. It thus appears quite important to study the welfare implications of housing price appreciation driven by a decrease in interest rates.

\section{FIGURE 4}

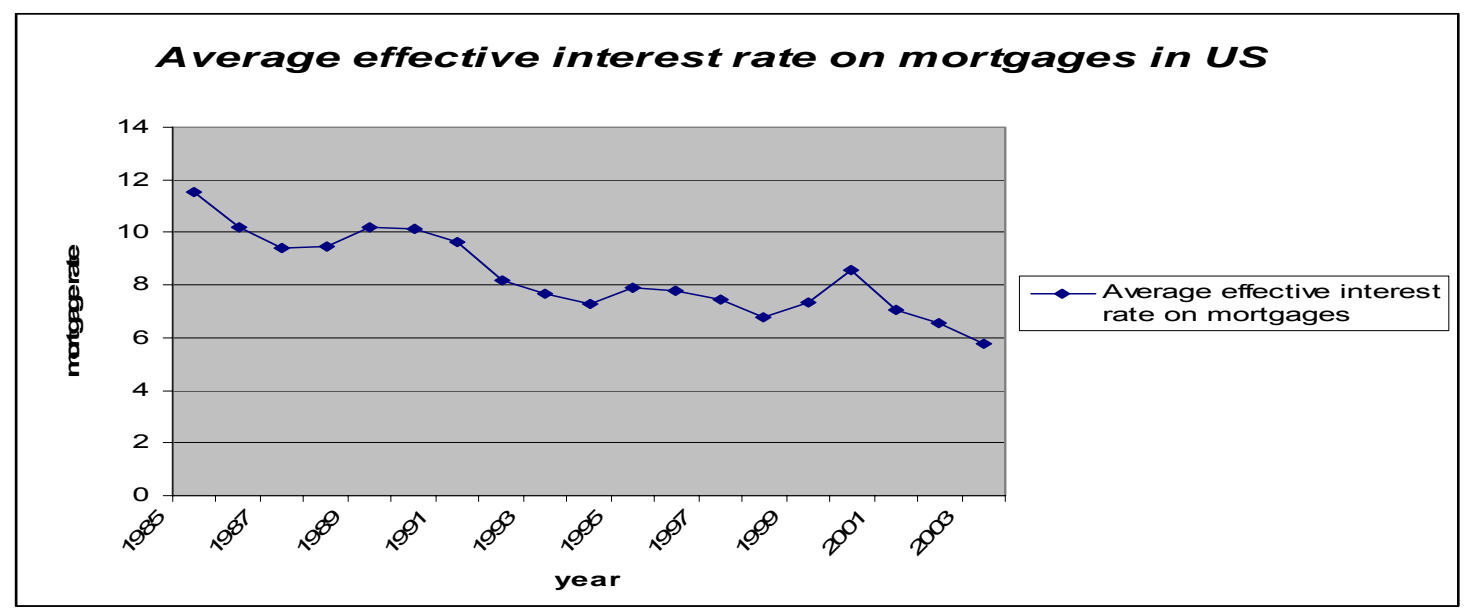

*Source: Federal Housing Finance Board (Monthly Interest Rate Survey)

\section{FIGURE 5}

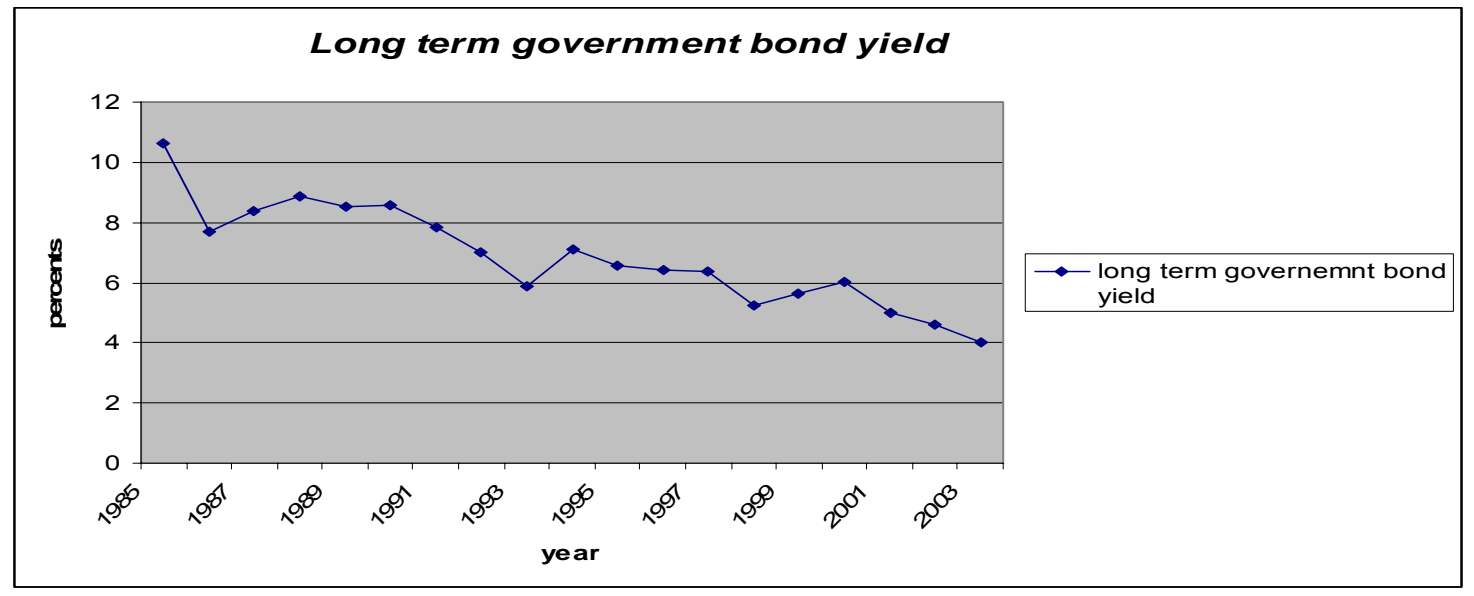

- Source: IMF International Financial Statistics

Let's now analyze what happens in the model economy when interest rates go down. As was already mentioned a decrease in the interest rates pushes up housing demand for both credit-constrained and unconstrained households. This leads to housing price appreciation. However, intuitively housing consumption in the new steady state should be higher for both credit-constrained and unconstrained households. The effect on 
consumption for unconstrained households is ambiguous since it depends on several factors. A decrease in the interest rate on bonds reduces their income, and the increase in housing consumption further depresses the consumption of the composite good. However, due to the increase in steady state housing price, households obtain capital gains on their housing stock, which allows them to increase consumption. Furthermore, the increase in housing prices creates a substitution effect from housing to consumption of other goods. Consequently, the total effect of an interest rate shock on consumption in the economy without credit constraints is ambiguous. In the economy with credit constraints the decrease in mortgage rates increases the disposable income of creditconstrained households, with an unambiguous positive effect on consumption. Since they also increase their housing stock, the total effect of a decline in the interest rate on their welfare should be positive.

The welfare adjustment, which is defined as in the previous sections, is derived from the following equation:

$$
\Delta V=\frac{\partial V}{\partial c} \cdot \frac{\partial c}{\partial i} \cdot \Delta i+\frac{\partial V}{\partial h}\left(\frac{\partial h}{\partial i}+\frac{\partial h}{\partial q} \cdot \frac{\partial q}{\partial i}\right) \cdot \Delta i+\frac{\partial V}{\partial y} \cdot \Delta y=0
$$

In the model without credit constraints the final welfare adjustment is given by: $\Delta y=\frac{\omega \cdot(1-\omega) \cdot \delta}{A^{2}} \cdot\left(y^{s s}-f\left\{\left\{x^{s s} \neq 0\right\}\right) \cdot \Delta+\frac{\left(i^{s s}+\delta-\pi\right) \cdot \omega \cdot(1-\omega)}{A^{2}} \cdot\left(y^{s s}-f 1\left\{x^{s s} \neq 0\right\}\right) \cdot \Delta-\frac{\omega\left(i^{i s}+\delta-\pi\right)}{A} \cdot\left(y^{s s}-f 1\left\{x^{s s} \neq 0\right\}\right) \cdot\left(\frac{(1-\omega) \cdot\left(q^{s s}-n\right) \cdot(1-\alpha)}{A \cdot\left(q^{s s}-n \cdot(1-\alpha)\right)}\right) \cdot \Delta v\right.$

By assumption $\Delta i$ is negative, which means that the second term which reflects the welfare improvement due to increased housing stock is negative. The third term, which reflects the decrease in housing consumption due to housing price appreciation, is positive implying a decrease in welfare. The first term which reflects the effect on the consumption of the composite good is positive. This implies that in my model a decrease in steady state consumption of unconstrained individuals due to higher investment in housing and a decline of return on bonds dominates the effect of capital gains and consequent substitution effect from housing toward consumption. The final direction of welfare change depends on the parameters. The result will be quantified and signed in the next section.

In the model with credit constraints, the welfare adjustment is given by: $\Delta y=\frac{1-\omega}{\omega \beta} \cdot\left(y^{s s}-f 1\left\{x^{s s} \neq 0\right\}\right)(1-\beta) \cdot\left(m-m^{2}\right) \cdot \Delta+\frac{B \cdot m}{\beta \cdot \omega D^{2}} \cdot\left(y^{s s}-f 1\left\{x^{s s} \neq 0\right\}\right) \Delta \dot{\Delta}+\frac{B \cdot m}{\beta \cdot \omega D} \cdot\left(y^{s s}-f 1\left\{x^{s s} \neq 0\right\}\right) \cdot\left(\frac{\left(q^{s s}-n\right) \cdot(1-\alpha)}{D \cdot\left(q^{s s}-n \cdot(1-\alpha)\right.}\right) \cdot \Delta i$ 
This result is quite similar to the previous one, but here the effect on composite good consumption, which is reflected in the first term, is positive as expected. The effect on housing stock, as in the previous case, depends on the interaction of a positive income effect and a negative substitution effect and is reflected in the second and third terms. This result is also quantified in the next section.

\section{US economy 1995-2004: Actual aggregate welfare adjustment}

In the previous sections, I derived theoretical results concerning welfare adjustments in a model economy where the housing price appreciates either because of supply or demand side shocks. However it is reasonable to think that housing price appreciation in the actual economy was driven by shocks both to demand as well as supply sides of the market. Empirical evidence provided above as well as theoretical results of the previous literature demonstrate that changes in the regulation costs, household income and interest rates were the major driving forces of housing price appreciation in the actual US economy from 1995 to 2004. Thus, in this section I calibrate the model and, using my theoretical welfare adjustments, compute the aggregate welfare adjustment in the actual US economy resulting from housing price appreciation from 1995 to 2004 driven by the given combination of the supply and demand side shocks mentioned above. I focus my analysis on this time period because, as Figure 1 shows, since the mid 90's the housing prices appreciated at unusually rapid rate.

To calculate the response of housing price to changes in income I need the values of $d \bar{L}$ and $n$. According to the US Census Bureau, which collects data on annual new residential construction, in 2004 1,532,000 single-family housing units with an average area of 2,349 square feet per unit and 310,000 units in buildings with two units or more with an average area of 1,173 square feet per unit were built. Thus in total $3,962,298,000$ square feet of housing were built in the US in 2004. Dividing the total number of square feet produced by the total number of housing units produced yields that the area of an average housing unit was 2,151 square feet. Since I have the average purchasing price in the US, which corresponds to an average housing unit it is more practical to define both the demand and the supply side in my model in terms of this average housing unit. Thus, let's assume that competitive firms decide how many 
housing units to produce given prices and regulation costs and the households decide how many housing units to consume. It is also convenient to define regulation costs in terms of this housing unit. According to US regulations a permit for constructing a housing unit with an area 1000-3000 square feet costs 800 dollars and an additional 400 dollars are necessary for application. Thus I set total cost of one permit $n=1,200$. According to a report of the National Association of Realtors, in 2003 (the most recent available estimate) in the US 658,000 acres of land were used for residential construction. Assuming that 1 unit of land in my model corresponds to 1acre of real land I set $\bar{L}=658,000$. Finally, since I have information about the total number of square feet produced and the total number of units of land used I calculate the amount of output per unit of land in the actual economy which is equal to $5,428.41$ square feet or 2.79 housing units.

With this information I calculate the construction cost per housing unit which is given by parameter $d$. In my model the output per unit of land is given by the following formula:

$h_{s t}=\left(\frac{\alpha \cdot q_{t}-\alpha \cdot n}{d}\right)^{(\alpha /(1-\alpha))}$

Solving this equation for $d$ I get:

$$
d=\left(\frac{\left(\alpha \cdot q_{t}-\alpha \cdot n\right)^{(\alpha /(1-\alpha))}}{h_{s, t}}\right)^{((1-\alpha) / \alpha)}
$$

As already mentioned $\mathrm{x}_{s, t}=2.79$ and according to results derived from the data of Monthly Interest Rate Survey of Federal Housing Finance Board average purchase price of housing in the US in 2003 was 262,000 dollars. Also based on the National Association of Realtors' data on capital income and land income shares in the housing construction industry I set $\alpha=0.4$. Substituting all the parameters into the last equation gives $d=22,386$ per one housing unit.

At this point I also need to specify the structure of the population or, in other words, number of credit-constrained and not credit-constrained households. It is possible to judge the degree of being credit-constrained by the current wealth or the accumulated wealth of the household. Even better indicator from this point of view can be the net worth of the household, that is, the value of the household's assets net of liabilities. The 2004 Survey of Consumer Finance by the Federal Reserve System reports the average 
net worth of American households according to the age of the household head (presented in Table 3).

TABLE 3 Net worth of US households by age

\begin{tabular}{|l|l|}
\hline Age of household head & $\begin{array}{l}\text { Mean net worth in constant } \\
2004 \text { dollars }\end{array}$ \\
\hline Under 35 & 73500 \\
\hline $35-44$ & 299200 \\
\hline $45-54$ & 542700 \\
\hline $55-64$ & 843800 \\
\hline $65-74$ & 690900 \\
\hline 75 and over & 528100 \\
\hline
\end{tabular}

Based on this data it is straightforward that households headed by individuals of the lowest two age groups are the most likely to be constrained. However, households headed by individuals of the age 35-44 have considerably higher net worth than do younger households. Moreover, according to the US Census Bureau, households headed by individuals aged 35-44 have the second highest median income in the US economy. Consequently, in my research I consider two different variants of parametrization. Under the first one households headed by individuals of the aged 35-44 are assumed to be credit-constrained; under the second one they are considered unconstrained. Using Current Population Report of US Department of Commerce I set $J_{c}=44784339$ and $J_{u c}=62888650$ for the first case and $J_{c}=21737795$ and $J_{u c}=85935104$ for the second case, where $J_{c}$ and $J_{u c}$ is the number of credit-constrained and unconstrained households respectively.

I also perform this computational exercise for both values of $\omega$ calculated in Section 5 , that is $\omega=0.56$ and $\omega=0.64$. I set $i^{s s}=0.057$ for the constrained economy, which was the level of the average effective mortgage rate in the US in 2004 and set $i^{s s}=0.039$ for the unconstrained economy which was the level of long-term government bond yield in the US in 2004. The remaining parameters were already defined in Section 5.

With this information it is easy to calculate an implied cumulative welfare adjustment for the actual economy. According to constant-quality housing price index of the US Census Bureau, housing prices increased by 43.7\% between 1995 and 2004. 
Also, median household income in the US increased by 30.1\% between 1995 and 2004. Finally, the interest rate on long-term government bonds declined from 6.58 to $3.9 \%$ (by 39.7\%) during this period while the effective interest rate on mortgages declined from 8 to $5.7 \%$ (by $28.7 \%$ ). The only unobservable is the change in the building permit cost or the supply-side shock. The idea is to calculate the elasticity of housing prices with respect to income and interest rates in both a constrained and an unconstrained economy and then to compute the total response of housing prices on changes in demand-side factors by multiplying the computed elasticities by the actual changes in those factors and summing the results. Then the supply-side shock or change in regulation costs can be computed so as to match the residual change in prices in the US economy.

To compute the response of housing prices to changes in demand side factors I use the following formulas

$$
\begin{aligned}
& \varepsilon_{q y, u c}=\frac{J \cdot \delta \cdot \omega \cdot d^{\alpha /(1-\alpha)}}{A \cdot q^{s s} \cdot \bar{L} \cdot \frac{\alpha^{2}}{1-\alpha} \cdot\left(\alpha \cdot q^{s s}-\alpha \cdot n\right)^{\frac{\alpha}{1-\alpha}-1}+A \cdot \bar{L} \cdot\left(\alpha \cdot q^{s s}-\alpha \cdot n\right)^{\frac{\alpha}{1-\alpha}} \cdot \frac{y^{s s}}{q^{s s}}} \\
& \varepsilon_{q y, c}=\frac{J \cdot \delta \cdot(d)^{\alpha /(1-\alpha)}}{q^{s s} \cdot \bar{L} \cdot D \cdot \frac{\alpha^{2}}{1-\alpha} \cdot\left(\alpha \cdot q_{s s}-\alpha \cdot n\right)^{\frac{\alpha}{1-\alpha}-1}+\bar{L} \cdot D \cdot\left(\alpha \cdot q^{s s}-\alpha \cdot n\right)^{\frac{\alpha}{1-\alpha}} \cdot \frac{y^{s s}}{q^{s s}}} \\
& \varepsilon_{q i, u c}=\frac{(1-\omega) \cdot(1-\alpha) \cdot i^{s s} \cdot\left(q^{s s}-n\right)}{A \cdot\left(q_{s s}-n \cdot(1-\alpha)\right)} \\
& \varepsilon_{q i, c}=\frac{m \cdot(1-\alpha) \cdot i^{s s} \cdot\left(q^{s s}-n\right)}{\omega \cdot D \cdot\left(q_{s s}-n \cdot(1-\alpha)\right)}
\end{aligned}
$$

where $\varepsilon_{\mathrm{qy}, \mathrm{c}}$ is the elasticity of price with respect to income in the constrained economy, $\varepsilon_{\mathrm{qy}, \mathrm{uc}}$ is the elasticity of price with respect to income in the unconstrained economy, $\varepsilon_{\mathrm{qi}, \mathrm{c}}$ is the elasticity of price with respect to interest rate in the constrained economy and $\varepsilon_{\mathrm{qi}, u c}$ is the elasticity of price with respect to interest rate in the unconstrained economy.

Substituting all the parameters into the last four equations yields the results displayed in Table 4: 
TABLE 4: Housing price elasticities under different parametrizations

\begin{tabular}{|l|r|r|r|r|}
\hline & $\begin{array}{l}J_{\mathrm{c}}=44784339 \\
J_{\mathrm{uc}}=62888650 \\
\omega=0.56\end{array}$ & $\begin{array}{l}\mathrm{J}_{\mathrm{c}}=44784339 \\
\mathrm{~J}_{\mathrm{uc}}=62888650 \\
\omega=0.64\end{array}$ & $\begin{array}{l}\mathrm{J}_{\mathrm{C}}=21737795 \\
\mathrm{~J}_{\mathrm{uc}}=85935104 \\
\omega=0.56\end{array}$ & $\begin{array}{l}\mathrm{J}_{\mathrm{c}}=21737795 \\
\mathrm{~J}_{\mathrm{uc}}=85935104 \\
\omega=0.64\end{array}$ \\
\hline$\varepsilon_{\text {qy,uc }}$ & 0.389 & 0.472 & 0.526 & 0.678 \\
\hline$\varepsilon_{\text {qy, }}$ & 0.264 & 0.382 & 0.188 & 0.281 \\
\hline$\varepsilon_{\text {qi,uc }}$ & 0.235 & 0.264 & 0.235 & 0.264 \\
\hline$\varepsilon_{\text {qi,c }}$ & 0.357 & 0.38 & 0.357 & 0.38 \\
\hline
\end{tabular}

From the table it is evident that if assuming that households headed by individuals in the age group 35-44 are not constrained, the model-implied elasticities with respect to income changes are quite high in the unconstrained economy. Given the elasticities with respect to the other shocks under such calibration the model-implied change in housing price from actual changes in incomes and interest rates overshoots the actual qualityadjusted change in housing prices. Thus, I use the case with $J_{c}=44784339$ and $J_{u c}=62888650$ in what follows. Also, since there are more unconstrained households in the US economy than constrained ones I use $\omega=0.56$. Using elasticities from the first column of the table and the fact that incomes changed by $30.1 \%$, the effective interest rate on mortgage changed by $28.7 \%$ and the nominal interest rate on bonds changed by $39.7 \%$, I obtain that in total the housing prices changed by $39.1 \%$ due to a change in demand-side factors. Since in total between 1995 and 2004 housing prices changed by $43.7 \%$ the change in housing price due to supply shock should have been equal to $4.6 \%$. I use the elasticity of housing prices with respect to regulation cost which is given by the following formula:

$\varepsilon_{q s}=\frac{\alpha \cdot n}{\left(q_{s s}-n \cdot(1-\alpha)\right)}$

Calculating this formula yields that $\varepsilon_{q s}=0.053$. This implies that the building permit cost should have increased by $86.7 \%$ to match the actual change in housing price. Since the new building permit cost is equal to 1200 dollars, the old one would have been 643 dollars, which implies the change of building permit cost of 557 dollars.

Now I use the changes of variables in units rather than in percents to calculate the dollar value of the welfare adjustment resulting from housing price appreciation driven by all factors jointly. Thus $\Delta n=557, \Delta y_{o}=10258, \Delta i_{c}=-2.3$ and $\Delta i_{n c}=-2.68$. Based 
on the American Housing Survey I set $f 1\left\{x^{s s} \neq 0\right\} \equiv 3074$, which was the level of average housing transaction costs in US in 2004.

Now I can calculate separately the welfare adjustment resulting from each shock in both a credit-constrained and unconstrained economy. The welfare adjustment in the unconstrained economy due to a change in building permit cost is given by:

$$
\Delta y_{s, u c}=\Delta n \cdot \omega \cdot\left(i^{s s}+\delta-\pi\right) \cdot\left(\frac{y^{s s}-f 1\left\{x^{s s} \neq 0\right\}}{A}\right) \cdot\left(\frac{\alpha}{q^{s s}-n \cdot(1-\alpha)}\right)=257
$$

Welfare adjustment in the unconstrained economy due to a change in building permit cost is given by:

$$
\Delta y_{s, c}=\Delta n \cdot \omega \cdot \frac{\alpha}{q^{s s}-n \cdot(1-\alpha)} \cdot\left(\frac{B}{\beta} \cdot \frac{1}{1-\omega} \cdot\left(\frac{y^{s s}-f 1\left\{x^{s s} \neq 0\right\}}{D}\right)\right)=296
$$

Welfare adjustment due to changes in steady state income in the unconstrained economy is given by:

$\Delta y_{y . u c}=-\frac{(1-\omega) \cdot\left(i^{s s}+\delta-\pi\right)}{A} \cdot \Delta y_{o}-\left(i^{s s}+\delta-\pi\right) \cdot\left(\frac{\omega}{A}-\frac{\omega \cdot\left(y^{s s}-f 1\left\{x^{s s} \neq 0\right\}\right)}{A \cdot q^{s s}} \cdot \frac{\partial q}{\partial y}\right) \cdot \Delta y_{o}=-10,770$

Consistent with prior expectations, the income effect on housing dominates the substitution effect and the steady state housing demand in the new steady state remains at a higher level than in the old steady state. Welfare adjustment due to increase in steady state income in credit-constrained economy is given by:

$$
\Delta y_{y, c}=-\frac{B \cdot(1-\omega)}{\omega \cdot \beta \cdot D} \cdot \Delta y_{o}-\frac{B}{\beta} \cdot\left(\frac{1}{D}-\frac{y^{s s}-f 1\left\{x^{s s} \neq 0\right\}}{D \cdot q^{s s}} \cdot \frac{\partial q}{\partial y}\right) \cdot \Delta y_{o}=-8,936
$$

Welfare adjustment due to changes in steady state interest rates in the unconstrained economy is given by:

$$
\begin{aligned}
& \Delta y_{i, u c}=\frac{\left(i^{s s}-\pi\right) \cdot \omega(1-\omega)}{A^{2}} \cdot\left(y^{s s}-f 1\left\{x^{s s} \neq 0\right\}\right) \cdot \Delta i-\frac{\omega\left(i^{s s}+\delta-\pi\right)}{A} \cdot\left(y^{s s}-f 1\left\{x^{s s} \neq 0\right\}\right) \cdot\left(\frac{(1-\omega) \cdot\left(q^{s s}-n\right) \cdot(1-\alpha)}{A \cdot\left(q^{s s}-n \cdot(1-\alpha)\right)}\right) \cdot \Delta i= \\
& =-1,746
\end{aligned}
$$

Finally welfare adjustment due to change in interest rate in the constrained economy is given by:

$$
\Delta y_{i, c}=-32,735
$$


Given these results it is easy to calculate the cumulative aggregate welfare change in the actual US economy in 1995-2004. To make my result more informative I express the final cumulative welfare adjustment per household in terms of mean income in the US in 2004 which was equal to 69,960 dollars. For computing the cumulative welfare adjustment I express each of the welfare adjustments calculated above as the percentage of mean income in 2004. I then sum those percentages across shocks for each group of households and multiply the results by the number of households in each group. Finally I sum the resulting terms for credit-constrained and unconstrained households and divide the result by the total number of households to obtain the final aggregate welfare adjustment per household as the percentage of median household income.

Thus the total aggregate welfare adjustment is given by

$$
\Delta Y_{\text {aggregate }}=\frac{J_{c}}{J_{u c}+J_{c}} \cdot \frac{\left(\Delta y_{s, c}+\Delta y_{y, c}+\Delta y_{i, c}\right)}{y_{\text {mean }}}+\frac{J_{u c}}{J_{u c}+J_{c}} \cdot \frac{\left(\Delta y_{s, u c}+\Delta y_{y, u c}+\Delta y_{i, u c}\right)}{y_{\text {mean }}}=-0.405
$$

Since the sign of the adjustment is negative according to my definition, the result implies the improvement of aggregate welfare. Thus, the housing price appreciation which took place in the US economy between 1995 and 2004 and which was driven by an observed combination of demand and supply side factors improved the aggregate welfare per household by around 40\% of mean household income in 2004 per household. Consequently, even in the economy with endogenous housing price the main conclusion of Section 2 that is the fact that housing price appreciation can actually imply the improvement in aggregate welfare remains unchanged. This result again confirms the result of Campbell and Cocco (2004), who found that an increase in housing price growth rate leads to an increase in consumption growth rate.

\section{Robustness check: The case with power utility function separable in composite consumption and housing consumption}

In the special case of models with endogenous price, when preferences are given by the Cobb-Douglass form the results of endogenous housing price appreciation driven by negative supply-side shocks are unambiguous since neither consumption nor borrowing changes because of a change in housing price. One should ask, however, what would be the effects of housing price appreciation if the preferences were given by a more general 
form. In this section I derive and then discuss the possible implications of assuming that preferences follow a power utility separable in housing and composite consumption.

Assume that the utility function is of the following form:

$$
u\left(c_{t}, h_{t}\right)=\frac{c^{1-\gamma}}{1-\gamma}+\theta \cdot \frac{h^{1-\sigma}}{1-\sigma}
$$

Let's first consider the economy with endogenous price. Using equation (18), substituting into it the above utility form and expressing $c^{s s}$ from the resulting equation yields:

$$
c^{s s}=\left(h^{s s}\right)^{(\sigma / \gamma)} \cdot \frac{\left(q^{s s} \cdot\left(i^{s s}+\delta-\pi\right)\right)^{(1 / \gamma)}}{\theta^{(1 / \gamma)}}
$$

Then substituting this into (16), rearranging terms and assuming that $\theta \neq 0$ produces:

$$
\left(h^{s s}\right)^{(\sigma / \gamma)} \cdot\left(q^{s s} \cdot\left(i^{s s}+\delta-\pi\right)\right)^{(1 / \gamma)}-\theta^{(1 / \gamma)} \cdot\left(y^{s s}-f 1\left\{x^{s s} \neq 0\right\}-q^{s s} \cdot \delta \cdot h^{s s}\right)=0
$$

I am not able to calculate analytically $h$ as a function of $q$ from this equation. However, it is evident that $h$ is no longer a simple linear function of $q$ so in the steady state $c$ should also depend on $q$. Moreover, since all other components in this equation are parameters, this equation implicitly defines $h$ as a function of $q$. Thus it is possible to use the implicit function theorem to get $\frac{\partial h}{\partial q}$. Calculating the derivatives I get the following expression:

$$
\frac{d h}{d q}=-\frac{\left(h^{s s}\right)^{(\sigma / \gamma)} \cdot(1 / \gamma) \cdot\left(q^{s s} \cdot\left(i^{s s}+\delta-\pi\right)\right)^{\left(\frac{1}{\gamma}-1\right)} \cdot\left(i^{s s}+\delta-\pi\right)+\theta^{(1 / \gamma)} \cdot \delta \cdot h^{s s}}{(\sigma / \gamma) \cdot\left(h^{s s}\right)^{\left(\frac{\sigma}{\gamma}-1\right)} \cdot\left(q^{s s} \cdot\left(i^{s s}+\delta-\pi\right)\right)^{(1 / \gamma)}+\theta^{(1 / \gamma)} \cdot q^{s s} \cdot h^{s s}}<0
$$

Now the change in the value function due to the change in $\mathbf{n}$ will be defined in the followingway:

$$
\begin{aligned}
& \Delta V=\frac{\partial V(h, b, y)}{\partial h} \cdot \frac{d h}{d q} \cdot \frac{\partial q}{\partial n} \cdot \Delta n+\frac{\partial V}{\partial c}\left(\frac{\partial c}{\partial q}+\frac{\partial c}{\partial h} \cdot \frac{\partial h}{\partial q}\right) \cdot \frac{\partial q}{\partial n} \cdot \Delta n+\frac{\partial V}{\partial y} \cdot \Delta y=\Delta n \cdot \frac{\partial q}{\partial n} \cdot\left(\frac{\partial u}{\partial h} \cdot \frac{d h}{d q}+\frac{\partial u}{\partial c} \cdot\left(-\delta \cdot h^{s s}-\delta \cdot q^{s s} \cdot \frac{d h}{d q}\right)\right)+ \\
& +\frac{\partial u}{\partial c} \cdot \Delta y=0
\end{aligned}
$$

where the marginal utilities of housing and consumption can be calculated from the utility form, and the derivative of housing stock over price is given by (37) .

Deriving from here $\Delta y$ I will have: 


$$
\Delta y=-\Delta n \cdot \frac{\partial q}{\partial n} \cdot \theta \cdot \frac{\left(c^{s s}\right)^{\gamma}}{\left(h^{s s}\right)^{\sigma}} \cdot \frac{d h}{d q}+\Delta n \cdot \frac{\partial q}{\partial n} \cdot \delta\left(h^{s s}+q^{s s} \cdot \frac{d h}{d q}\right)
$$

Examining (38) we see that the first term is positive and the second term, which defines the interaction between substitution and income effects on consumption, can be either positive or negative depending on which effect is higher. So the final sign of this expression and thus the answer to the question of whether housing price appreciation implies a welfare loss or gain for individuals can be defined only after calibrating the model and explicitly calculating (38). Intuitively, there can be two cases. Either the individual will end up with lower housing consumption but higher composite good consumption and possible welfare improvement, or he will end up with lower housing and lower good consumption which implies an even higher welfare loss than in the economy with Cobb-Douglass preferences. It is not possible to calculate analytically the steady state allocations of housing and consumption in this economy so I have to resort to numerical methods. $h^{\text {ss }}$ can be calculated from (36) assuming a certain level of prices. Thus, I guess the initial price and solve the equation (which is a nonlinear equation in $h$ ) by using the Newton method for nonlinear equations. I then calculate the supply of new housing given this price and afterwards substitute the demand and the supply into the market clearing condition. If under the first assumed price the market does not clear, I update my guess and again calculate the implied demand and supply and check the market clearing condition. I repeat this procedure until finding a price which equates demand and supply. After having found the equilibrium price and equilibrium level of housing stock, it is easy to calculate $c^{s s}$ from (35). I then calculate the expression in (37). Finally, $\frac{\partial q}{\partial n}$ can be calculated, as in previous cases, from the market clearing condition for the housing market. After these initial procedures I can calculate the welfare adjustment in (38).

For this exercise I set $\theta=1.5 \sigma=2$ and $\gamma=3$ (following Campbell and Cocco (2005)). The other parameters are the same as in the previous model. From computations I get that the total effect on consumption in this economy is positive since $h^{s s}+q^{s s} \cdot \frac{d h}{d q}=-5.36$. This implies that under more general utility the economy ends up with still lower housing consumption but higher consumption level. Intuitively this result implies that under a separable power utility function the aggregate welfare 
improvement should be even higher than in the Cob Douglas case since the loss due to the supply side shock is lower.

Analysis of the case of different preferences in the model with binding credit constraints and endogenous prices gives even more interesting results. In this case, there will be additional effects on the steady state level of borrowing resulting from the relaxation of credit constraint due to the housing price appreciation. In this economy, the steady state level of consumption is given by:

$$
c^{s s}=\left(h^{s s}\right)^{(\sigma / \gamma)} \cdot \frac{\left.\left(q^{s s} \cdot B\right)\right)^{(1 / \gamma)}}{(\theta \cdot \beta)^{(1 / \gamma)}}
$$

Substituting this into (25), using the expression for $b^{s s}$ and applying the implicit function theorem gives:

$$
\frac{d h}{d q}=-\frac{\left(h^{s s}\right)^{(\sigma / \gamma)} \cdot(1 / \gamma) \cdot\left(q^{s s} \cdot B\right)^{\left(\frac{1}{\gamma}-1\right)} \cdot B+(\theta \cdot \beta)^{(1 / \gamma)} \cdot h^{s s} \cdot\left(\delta+\left(i^{s s}-\pi\right) \cdot m\right)}{(\sigma / \gamma) \cdot\left(h^{s s}\right)^{\left(\frac{\sigma}{\gamma}-1\right)} \cdot\left(q^{s s} \cdot B\right)^{(1 / \gamma)}+(\theta \cdot \beta)^{(1 / \gamma)} \cdot q^{s s} \cdot\left(\left(i^{s s}-\pi\right) \cdot m+\delta\right)}<0
$$

Again $h$ in this economy is a non-linear function of $q$. By looking at the credit constraint written in the steady state (see appendix part 2) we see that not only consumption but also borrowing will change due to the change in the steady state price. Thus, besides the usual substitution and income effects on consumption present in the previous model, there will be an additional indirect effect on consumption coming through either increased or decreased borrowing (depending on the relative magnitude of the change in the steady state price and housing stock).

Equating change in the value function to zero, substituting all the components in it and expressing $\Delta y$ from resulting equation, I get the final formula of the welfare adjustment for this economy:

$$
\Delta y=-\Delta n \cdot \frac{\partial q}{\partial n} \cdot \theta \cdot \frac{\left(c^{s s}\right)^{\gamma}}{\left(h^{s s}\right)^{\sigma}} \cdot \frac{d h}{d q}+\Delta n \cdot \frac{\partial q}{\partial n} \cdot\left(\delta+m \cdot\left(i^{s s}-\pi\right)\right) \cdot\left(h^{s s}+q^{s s} \cdot \frac{d h}{d q}\right)
$$

where $\frac{d h}{d q}$ is given by (39).

This implies that if the final effect on consumption in the model with binding credit constraints is positive, it can be larger in this case than in the case without credit constraints since credit-constrained households get an additional benefit because of the possibility of an increase in borrowing due to the relaxation of the credit constraint. 
Applying the same procedure as in the previous case I get that in this model $h^{s s}+q^{s s} \cdot \frac{d h}{d q}=-5.16$. Using the already defined values parameters I calculate the second terms in (40) and (38) and obtain $-0.286 \cdot \Delta n \cdot \frac{\partial q}{\partial n}$ and $-0.225 \cdot \Delta n \cdot \frac{\partial q}{\partial n}$ respectively. Since I take the same change in regulation costs in both economies response of price on shock should be also the same in both economies. Thus I can conclude that positive effect on consumption is higher in the constrained economy.

\section{Conclusion}

In this paper I have explored the effects of housing price appreciation in an economy with binding credit constraints and endogenous housing prices. I have extended Bajari et al (2005), who find that in an economy with unconstrained households and exogenous housing price the housing price appreciation implies no significant effects on aggregate welfare. My results show that if credit constraint is incorporated into Bajari et al's model with exogenous housing price, housing price appreciation implies an improvement in aggregate welfare. I have also analyzed a model with endogenous housing price in which housing price appreciation is driven by supply and demand side shocks. Both credit-constrained and unconstrained versions of this model have been studied. After deriving the theoretical welfare adjustments resulting from each of the shocks affecting housing price I calculated the total effect of housing price appreciation in the US from 1995 to 2004 on aggregate welfare. My results imply that the housing price appreciation observed during this period in US led to per household improvement in the aggregate welfare by around $40 \%$ of mean household income in the US in 2004.

One of the straightforward extensions of this model would be the inclusion of renters into the analysis. The current model does not explicitly incorporate the possibility of renting a house versus owning it. Depending on the structure of the market, renters can either be better or worse off due to case of housing price appreciation. They will experience a net welfare loss due to housing price appreciation in a perfectly competitive rental market. Under such an assumption, the housing price should be equal to the net present value of future rents and thus housing price appreciation will immediately drive up the rents, which directly hurts those households. Moreover, they 
would have no gain from the positive price shock, since they do not own any housing stock. However, if the rise in housing prices is driven by a speculative bubble, then the rise in housing price can be accompanied by a fall in rents, creating a positive welfare adjustment for renters. Looking at the data on real rents in EU countries provided by the ECB publication Structural factors in EU housing markets one can see that during the 90s rents rose in a majority of EU countries which speaks for the first case. Thus, explicitly including the renting decision implies additional negative effects on aggregate welfare and would make my result concerning aggregate welfare adjustment more accurate. Also, it would be interesting to measure the relative strength of this effect versus the effect of borrowing constraint relaxation.

Another shortcoming of the present model is that credit constraint is applied to all the households independent of their age, life cycle stage and wealth position. However, only part of the households in the real economy is actually credit-constrained, and only for those households are these constraints likely to be binding. If one looks at the empirical profile of lifetime earnings of typical household, the earnings begin to grow from their 20's, reach their peak at mid 30's or around 40 and then decline again. Consequently the issue of housing price appreciation could be studied in more realistic setting consistent with a lifetime earnings profile, if I model the economy in an overlapping generations' setup with three generations (young, middle age and old) and with only young households being credit-constrained.

The model can also be used for studying two additional issues. The first issue is the effect of demographic factors, such as population growth, on the housing market and choice of housing stock. The basic intuition is that population growth will affect the composition of households from the point of view of being credit-constrained. Thus it can be interesting to study the effects of housing price appreciation on the aggregate welfare taking into account changes in demographic factors. Moreover, political reasons which underlie the endogenous price change in my model can also be endogenized. One can incorporate some political (voting) mechanisms that will allow regulation costs to be determined by the optimal decision of households. In such an economy housing prices as well as aggregate welfare will depend not only on purely economic factors but also on political interaction of young credit-constrained homeowners and renters and older homeowners. 


\section{References}

Aghion, P. and Bachetta, P., "Financial development and the instability of open economies", NBER Working Paper 10246, 2004

Amin, K. and Capozza, D., "Sequential Development" Journal of Urban Economics, $34,142-158,1993$

Bajari, P., Lanier Benkard, C. and Krainer, J., "House prices and consumer welfare", Journal of Urban Economics, 58, 474-488, 2005

Campbell, J. and Cocco, J., "How do house prices affect consumption? Evidence from micro data", NBER Working Paper 11534, 2005

Case, K., Quigley, J. and Shiller, R., "Comparing wealth effects: Stock market versus housing market" Cowles Foundation Discussion Paper 1335, 2001

Cheesman, J., "Projections of the number of households and families in the United States: 1995 to 2010", US .Bureau of the Census, Current Population Reports, P251129, 1996

Dougherty, A. and Van Order R., "Inflation, housing costs and the Consumer Price Index" American Economic Review, 72, 154-164, 1982

Glaeser, E. and Guyourko, J., "Why have housing prices gone up?" American Economic Review, 95, 329-359, 2005

Iacoviello, M., "House prices, borrowing constraints and monetary policy in the business cycle" American Economic Review, 95, 739-764, 2005

Iacoviello M., "Consumption, house prices and collateral constraints: Structural Econometric Analysis", Boston College Working Papers in Economics 589, 2004

Iacoviello M., Minetti R, "Financial Liberalisation and the Sensitivity of House Prices to Monetary Policy: Theory and Evidence" Boston College Working Papers in Economics 538, 2003

Kiyotaki N. and Moore J., "Credit cycles” Journal of Political Economy, 105, 211-248, 1997

Li, W. and Yao, R., "The life cycle effects of house price changes", Federal Reserve Bank of Philadelphia Working Paper 05-7, 2005

Lehnert, A., "Housing, Consumption and Credit Constraints" Finance and Economics Discussion Series, 63, 2004

Margolis, E.," Housing depreciation: An empirical consideration of the filtering hypotheses" Review of Economics and Statistics, 64, 90-96, 1982 
Malpezzi, M. and Ozanne, L., "Microeconomic estimates of housing depreciation" Land Economics, 63, 372-385, 1987

Mc. Farlane, A., "Rent Stabilization and the long-run supply of housing" US Department of Housing and Urban Development, Office of policy development and research, 2001

Mendoza, G. and Durdu, C., "Putting the brakes on sudden stops: The financial frictions-moral hazard tradeoff of asset price guarantees "NBER Working Paper 10790, 2004

Nothaft, F., "The contribution of home value appreciation to the US economic growth" Urban Policy and Research, 22, 23-34, 2004

Ortalo-Magne, F. and Rady, S., "Housing market dynamics: On the contribution of income shocks and credit constraints" Review of Economic Studies, 73, 459-485, 2006

Tsaratonis, K. and Zhu, H., "What drives housing price dynamics: cross-country evidence”, BIS Quarterly Review, 2004

"Structural factors in the EU housing market", European Central Bank, 2003

Existing Home Sales Series, National Association of Realtors:

http://www.realtor.org/Research.nsf/files/EHSreport.XLS/\$FILE/EHSreport.XLS

Monthly Interest Rate Survey, Federal Housing Finance Board: http://www.fhfb.gov/Default.aspx?Page $=53$

Historical Income Tables, US Census Bureau:

http://www.census.gov/hhes/www/income/histinc/histinctb.html

American Housing Survey, US Census Bureau

http://www.census.gov/hhes/www/housing/ahs/nationaldata.html 


\section{Appendix}

\section{Derivation of steady state in the economy with endogenous housing price}

According to steady state definition:

$h_{t+1}=h_{t}=h^{s s}$

$c_{t+1}=c_{t}=c^{s s}$

$b_{t+1}=b_{t}=b^{S S}=0$

$x^{s s}=h^{s s}-(1-\delta) \cdot h^{s s}=\delta \cdot h^{s s}$

$c^{s s}=y^{s s}-f 1\left\{x_{s s} \neq 0\right\}-q^{s s} \cdot \delta \cdot h^{s s}$

Using conditions (14) and (15) and substituting (29) into (15) I get:

$\beta=\frac{1}{i^{s s}+(1-\pi)}$

$q^{s s} \cdot\left(i^{s s}+\delta-\pi\right)=\frac{\partial u(c, h)}{\partial h} \div \frac{\partial u(c, h)}{\partial c}$

Now to proceed I need to assume a concrete form of utility function. In this paper I follow Li and Yao (2004) and assume a modified Cobb-Douglas utility of the form:

$$
u\left(c_{t}, h_{t}\right)=\frac{\left(c^{1-\omega} \cdot h^{\omega}\right)^{1-\gamma}}{1-\gamma}
$$

This form is quite convenient since it allows me to obtain analytical solutions for the steady state. However with different assumptions about utility one can get additional effects on consumption since substitution and income effect will not cancel each other. I will discuss this issue later.

Using (31), taking derivatives and plugging into (30)

$$
q^{s s}\left(i^{s s}+\delta-\pi\right)=\frac{c^{s s}}{h^{s s}} \cdot \frac{\omega}{1-\omega}
$$

and rearranging gives

$$
c^{s s}=h^{s s} \cdot q^{s s} \cdot\left(i^{s s}+\delta-\pi\right) \cdot \frac{1-\omega}{\omega}
$$

Substituting this into (28) and making some rearrangements I get: 
$q^{s s} \cdot h^{s s} \cdot\left(\frac{(1-\omega) \cdot i^{s s}+\delta-(1-\omega) \cdot \pi}{\omega}\right)=y^{s s}-f 1\left\{x^{s s} \neq 0\right\}$

Thus, the steady state level of housing stock is given by the following:

$h^{s s}=\frac{\omega \cdot\left(y^{s s}-f 1\left\{x^{s s} \neq 0\right\}\right)}{A \cdot q^{s s}}$

where $A=(1-\omega) \cdot i^{s s}+\omega \cdot \pi+\delta-\pi$

Then substituting (21) into (20) I get

$c^{s s}=\frac{(1-\omega) \cdot\left(y^{s s}-f 1\left\{x^{s s} \neq 0\right\}\right) \cdot\left(i^{s s}+\delta-\pi\right)}{A}$

And finally

$$
x^{s s}=\delta \cdot h^{s s}=\delta \cdot \frac{\omega \cdot\left(y^{s s}-f 1\left\{x^{s s} \neq 0\right\}\right)}{A \cdot q^{s s}}
$$

Now the equilibrium housing price is determined endogenously by equating demand nd supply. Thus which defines equilibrium $\mathrm{q}^{\text {ss }}$ is given by:

$$
J \cdot \delta \cdot \frac{\omega \cdot\left(y^{s s}-f 1\left\{x^{s s} \neq 0\right\}\right)}{A \cdot q^{s s}}=\left(\frac{\alpha \cdot q^{s s}-\alpha \cdot n}{d}\right)^{(\alpha /(1-\alpha))} \cdot \bar{L}
$$

Rearranging it and assuming that $A$ is not equal to $0 \mathrm{I}$ get:

$(d)^{(\alpha /(1-\alpha))} \cdot J \cdot \delta \cdot \omega \cdot\left(y^{s s}-f 1\left\{x^{s s} \neq 0\right\}\right)-\left(A \cdot q^{s s} \cdot \bar{L} \cdot\left(\alpha \cdot q^{s s}-\alpha \cdot n\right)^{(\alpha /(1-\alpha))}\right)=0$

This is an implicit function which defines how the equilibrium price depends on regulation costs (parameter $n$ ), and in my model the price appreciation is driven by an increase in regulation costs. Thus, to determine how the equilibrium price changes in response to an increase in building permit cost I apply the implicit function theorem to this equation, which yields

$$
\frac{d q}{d n}=\frac{\alpha \cdot q^{s s}}{q^{s s}-n \cdot(1-\alpha)}>0
$$

since the numerator is positive and the denominator should be positive which is evident from (16) (capital to land ratio cannot be negative and (1- $\alpha$ ) is a number strictly less than one). 
2. Derivation of steady state in the economy with endogenous housing price and credit constraints.

The steady state of this economy under binding credit constraints is given by the following conditions:

$$
\begin{aligned}
& h_{t+1}=h_{t}=h^{s s} \\
& c_{t+1}=c_{t}=c^{s s} \\
& b_{t+1}=b_{t}=b^{s s} \\
& b^{s s}=-m \cdot q^{s s} \cdot h^{s s} \\
& s^{s s}=b^{s s}-(1-\pi) \cdot b^{s s}=\pi \cdot b^{s s} \\
& x^{s s}=h^{s s}-(1-\delta) \cdot h^{s s}=\delta \cdot h^{s s} \\
& c^{s s}=y^{s s}+i^{s s} \cdot b^{s s}-f 1\left\{x_{s s} \neq 0\right\}-q^{s s} \cdot \delta \cdot h^{s s}-\pi \cdot b^{s s}
\end{aligned}
$$

Defining Euler equations in a steady state yields:

$$
\begin{aligned}
& v^{s s}=\frac{\partial u\left(c^{s s}, h^{s s}\right)}{\partial c^{s s}} \cdot\left(1-\beta\left(i^{s s}+1-\pi\right)\right) \\
& q^{s s}=\beta \cdot\left(\frac{\partial u\left(c^{s s}, h^{s s}\right)}{\partial h^{s s}} \div \frac{\partial u\left(c^{s s}, h^{s s}\right)}{\partial c^{s s}}+q^{s s} \cdot(1-\delta)\right)+m \cdot q^{s s} \cdot\left(1-\beta \cdot\left(i^{s s}+1-\pi\right)\right)
\end{aligned}
$$

Using utility form (19) and substituting in (36) and (37) produces:

$$
\begin{aligned}
& v^{s s}=(1-\omega) \cdot\left(c^{s s}\right)^{(-\gamma)} \cdot\left(\frac{h^{s s}}{c^{s s}}\right)^{\omega^{*}(1-\gamma)} \cdot\left(1-\beta\left(i^{s s}+1-\pi\right)\right) \\
& q^{s s}=\beta \cdot\left(\frac{c^{s s}}{h^{s s}} \cdot \frac{\omega}{1-\omega}+q^{s s} \cdot(1-\delta)\right)+m \cdot q^{s s} \cdot\left(1-\beta \cdot\left(i^{s s}+1-\pi\right)\right)
\end{aligned}
$$

Using (40) I get

$$
c^{s s}=h^{s s} \cdot q^{s s} \cdot B \cdot \frac{1-\omega}{\omega \cdot \beta}
$$

where $B=1-\beta \cdot(1-\delta)-m\left(1-\beta \cdot\left(i^{s s}+1-\pi\right)\right)$

Now substituting (41) and the expression for steady state borrowing into (36) and rearranging I get:

$$
\begin{aligned}
& h^{s s}=\frac{y^{s s}-f 1\left\{x^{s s} \neq 0\right\}}{D \cdot q^{s s}} \\
& \text { where } \mathrm{D}=\frac{1-\omega}{\omega \cdot \beta} \cdot B-m \cdot \pi+i^{s s} \cdot m+\delta
\end{aligned}
$$


Then substituting (42) into (41), using steady state credit constraint (39) and using also steady state level of consumption I get steady state levels of consumption borrowing and the shadow price of borrowing given by Lagrange multiplier of the credit constraint $\left(v^{\mathrm{ss}}\right)$ :

$c^{s s}=\frac{y^{s s}-f 1\left\{x^{s s} \neq 0\right\}}{D} \cdot B \cdot \frac{1-\omega}{\omega \cdot \beta}$

$b^{s s}=m \cdot \frac{y^{s s}-f 1\left\{x^{s s} \neq 0\right\}}{D}$

$v^{s s}=(1-\omega) \cdot\left(\frac{y^{s s}-f 1\left\{x^{s s} \neq 0\right\}}{D} \cdot B \cdot \frac{1-\omega}{\omega \cdot \beta}\right)^{(-\gamma)} \cdot\left(\frac{\omega \cdot \beta}{q^{s s} \cdot B \cdot(1-\omega)}\right)^{\omega \cdot(1-\gamma)} \cdot\left(\left(1-\beta \cdot\left(i^{s s}+1-\pi\right)\right)\right.$

Finally $\mathrm{q}^{\mathrm{ss}}$ is calculated as previously from market clearing condition: $J \cdot \delta \cdot \frac{y^{s s}-f 1\left\{x^{s s} \neq 0\right\}}{D \cdot q^{s s}}=\left(\frac{\alpha \cdot q^{s s}-\alpha \cdot n}{d}\right)^{(\alpha /(1-\alpha))} \cdot \bar{L}$ 
Individual researchers, as well as the on-line and printed versions of the CERGE-EI Working Papers (including their dissemination) were supported from the following institutional grants:

- Center of Advanced Political Economy Research [Centrum pro pokročilá politickoekonomická studia], No. LC542, (2005-2009),

- Economic Aspects of EU and EMU Entry [Ekonomické aspekty vstupu do Evropské unie a Evropské měnové unie], No. AVOZ70850503, (2005-2010);

- Economic Impact of European Integration on the Czech Republic [Ekonomické dopady evropské integrace na ČR], No. MSM0021620846, (2005-2011);

Specific research support and/or other grants the researchers/publications benefited from are acknowledged at the beginning of the Paper.

(c) Ashot Tsharakyan, 2007

All rights reserved. No part of this publication may be reproduced, stored in a retrieval system or transmitted in any form or by any means, electronic, mechanical or photocopying, recording, or otherwise without the prior permission of the publisher.

Published by

Charles University in Prague, Center for Economic Research and Graduate Education (CERGE) and

Economics Institute ASCR, v. v. i. (EI)

CERGE-El, Politických vězňů 7, 11121 Prague 1, tel.: +420 224005 153, Czech Republic.

Printed by CERGE-EI, Prague

Subscription: CERGE-EI homepage: http://www.cerge-ei.cz

Editors: Directors of CERGE and EI

Managing editors: Deputy Directors for Research of CERGE and EI

ISSN 1211-3298

ISBN 978-80-7343-132-7 (Univerzita Karlova. Centrum pro ekonomický výzkum

a doktorské studium)

ISBN 978-80-7344-121-0 (Národohospodářský ústav AV ČR, v. v. i.) 
CERGE-EI

P.O.BOX 882

Politických vězňů 7

11121 Praha 1

Czech Republic http://www.cerge-ei.cz 